\title{
Intrathymic Selection and Defects in the Thymic Epithelial Cell Development
}

\author{
Javier García-Ceca ${ }^{1,2,+}$, Sara Montero-Herradón ${ }^{1,2,+}$ and Agustín G. Zapata ${ }^{1,2, *}$ \\ 1 Department of Cell Biology, Faculty of Biology, Complutense University of Madrid, 28040 Madrid, Spain; \\ jgarciaceca@bio.ucm.es (J.G.-C.); saramontero@ucm.es (S.M.-H.) \\ 2 Health Research Institute, Hospital 12 de Octubre (imas12), 28041 Madrid, Spain \\ * Correspondence: zapata@bio.ucm.es; Tel.: +34-91-394-4979 \\ + These authors contribute equally to the article.
}

Received: 7 September 2020; Accepted: 30 September 2020; Published: 2 October 2020

\begin{abstract}
Intimate interactions between thymic epithelial cells (TECs) and thymocytes (T) have been repeatedly reported as essential for performing intrathymic T-cell education. Nevertheless, it has been described that animals exhibiting defects in these interactions were capable of a proper positive and negative T-cell selection. In the current review, we first examined distinct types of TECs and their possible role in the immune surveillance. However, EphB-deficient thymi that exhibit profound thymic epithelial (TE) alterations do not exhibit important immunological defects. Eph and their ligands, the ephrins, are implicated in cell attachment/detachment and govern, therefore, TEC-T interactions. On this basis, we hypothesized that a few normal TE areas could be enough for a proper phenotypical and functional maturation of T lymphocytes. Then, we evaluated in vivo how many TECs would be necessary for supporting a normal T-cell differentiation, concluding that a significantly low number of TEC are still capable of supporting normal T lymphocyte maturation, whereas with fewer numbers, T-cell maturation is not possible.
\end{abstract}

Keywords: thymic epithelial cells; thymocyte education; regulatory T-cells; Eph/ephrins

\section{Introduction}

The immune system has developed several strategies to properly control the immune responses. These strategies allow peripheral $\mathrm{T}$ lymphocytes to respond strongly to non-self-antigen determinants presented by self-MHC molecules, whereas they do not elicit a response when confronted to self-antigens, avoiding the appearance of autoimmune syndromes. Central to this behavior is the positive selection of thymocytes in the thymic cortex and the removal of autoreactive T-cell clones (negative selection) in the medulla [1,2], as well as the generation of the so-called T regulatory (Treg) cells [3].

The thymus is a primary lymphoid organ derived from the endoderm of the 3rd pharyngeal pouch implicated in the maturation of thymocytes and, therefore, key for establishing the immune surveillance. This organ does not contain self-renewing lymphoid precursor cells and therefore, is colonized by lymphoid precursors coming either from the fetal liver through mesenchyme or from the adult bone marrow via the blood vessels [4]. Within the thymus, the developing thymocytes move throughout a 3D thymic epithelial (TE) network, interacting with the thymic epithelial cells (TECs) of two histologically different compartments: the cortex and the medulla [5].

Both $\mathrm{DN}\left(\mathrm{CD}^{-} \mathrm{CD} 8^{-}\right)$thymocytes, derived directly from the lymphoid precursor cells seeding the thymus and DP $\left(\mathrm{CD}^{+} \mathrm{CD}^{+}\right)$thymocytes, migrate throughout the cortical (c) epithelium. During this journey, cTEC present self-peptides with the concourse of MHC molecules to DP cells (see later). Those thymocytes whose TCR $\alpha \beta$ interact with peptide-MHC complexes with intermediate 
affinity/avidity will be positively selected and will differentiate to mature $\mathrm{SP}\left(\mathrm{CD} 4^{+} \mathrm{CD} 8^{-}\right.$or $\left.\mathrm{CD} 4^{-} \mathrm{CD} 8^{+}\right)$ cells [5]. Other DP thymocytes that do not recognize any MHC-peptide complexes will die by neglect [6].

Positively selected SP thymocytes up-regulate the expression of CCR7 and migrate into the medulla through the cortico-medullary junction to interact with medullary $(\mathrm{m})$ TECs that express ligands of CCR7 (i.e., CCL19, CCL21) [7]. mTECs have the capacity to present peptides derived from tissue proteins (TSA, tissue specific antigens) expressed outside the thymus with the concourse of, at least, two different transcription factors: Autoimmune regulator (Aire) [5,8-11] and Forebrain embryonic Zn-finger-like (Fefz2) [12]. These mTEC-thymocyte interactions are essential for the induction of thymic selection, as thymocytes whose TCR $\alpha \beta$ recognize with high-affinity TSA are eliminated by apoptosis (negative selection) [5,10] or differentiate to Treg cells [3].

In the next sections, we will analyze in detail these processes and will describe some experimental models in which, despite profound alterations of the thymic epithelium, the intrathymic T-cell education seems to proceed properly. Finally, we will propose some possible explanations to this behavior.

\section{Thymic Epithelium Is Originated from Epithelial Progenitors (TEPCs) whose Nature Is Controversial}

As mentioned above, TE derives from the endoderm of the 3rd pharyngeal pouch [4]. In this early thymic primordium, a common bipotent thymic progenitor cell was identified capable of giving rise to both committed cTEC precursors and mTE progenitor cells [13-18]. However, the phenotype of these cells is a matter of discussion and other studies have reported the existence of lineage-specific progenitor cells either for cTECs or mTECs $[19,20]$. In this respect, it is important to remark that embryonic thymic epithelial progenitor cells (TEPCs) express cell markers (i.e., $\beta 5 t$, CD205, IL7) specific of the cTEC lineage of adult thymus [21-23]. These results supported a model of serial progression for explaining the establishment of two major TEC subsets, cortical and medullary. Recently, single cell-RNA sequencing analysis [24] confirmed that most embryonic TECs show a strong cTEC footprint. According to this model, TEPCs would be committed to the cortical epithelial cell lineage by default, whereas the differentiation into mTECs would require the activation of a medullary specific transcriptional program together with the downregulation of CTEC committed genes [10].

On the other hand, embryonic and adult TEPCs seem to be different. Some studies have reported that adult thymi do not contain TEPCs with characteristics of cTECs $[19,20]$ and others remark that bipotent TEPCs do exit in the adult thymus but exhibiting their own molecular characteristics [13-15,25]. In any case, adult TEPCs apparently lose their embryonic features, whereas committed progenitor cells either with cTEC or mTEC lineages appear $[15,19,20,24,26]$.

\section{Cortical Epithelium and Positive Selection}

Reported cTEC specific cell markers are few (i.e., K8, Ly51, CD205) and, consequently, it is difficult to establish conclusively both the phenotype and function of cTEC subsets. The existence of bipotent TEPCs has been reported in a small subset of CD $45^{-} \mathrm{EpCAM}^{+} \mathrm{Ly} 51^{\mathrm{lo}} \mathrm{UEA} 1^{-/ \mathrm{lo}} \mathrm{MHCII}{ }^{\mathrm{lo}}$ Int $\alpha 6^{\text {hi }}$ Sca- $1^{\text {hi }}$ TECs [14]. This epithelial cell population is radioresistant and proliferates during thymic regeneration [27]. Previously, Shakib et al. [28] had described a CD205 ${ }^{+} \mathrm{CD} 40^{-}$cTEC progenitor population enriched in proliferating cells that expressed lower levels of cTEC-specific transcripts (i.e., $\beta 5 t$ and cathepsin L), than the more mature cTECs. In addition, a small subset of CD205 ${ }^{+}$TECs has been reported as immature cTECs [21].

The cortical epithelium is involved in the maturation of DN thymocytes into DP cells through the production of IL7 $[29,30]$ and the surface expression of several Notch ligands, largely Delta-like 4 (D114) [31,32], and presents MHC-peptides to DP thymocytes, an essential process for their positive selection. However, it is unclear which cTEC subset is specifically involved in these functions. In adult thymic cortex, cTEC subsets can be immunohistochemically distinguished according to their levels of Ly51 expression. Ly51 $1^{\text {hi }}$ CTECs occupy both the cortico-medullary border and the subcapsule, whereas Ly51 $1^{\text {lo }}$ cells occur throughout the cortex. By flow cytometry, Ly51 ${ }^{\text {hi }}$ cTECs were MHCII ${ }^{\text {hi }}$ 
and the Ly51 ${ }^{\text {lo }}$ cell subset correlated with the MHCII ${ }^{l o}$ ones [33-35]. In addition, adult Ly51 ${ }^{\text {hi }}$ cTECs express Dl14, whereas most of the Ly51 ${ }^{\text {lo }}$ cell subset is D114- [35-38]. Accordingly, Ly51 hi cTEC might represent a niche for DN cells whereas Ly51 ${ }^{\mathrm{lo}}$ ones would constitute the niche where DP thymocytes are selected [35].

During their journey throughout thymic cortex, developing thymocytes undergo selection twice. DN3 (CD4 ${ }^{-} \mathrm{CD} 8^{-} \mathrm{CD} 44^{-} \mathrm{CD} 25^{+}$) cells rearrange the TCR $\alpha \beta$ alleles [39]; those successfully arranged TCR $\beta$ chains are associated with an invariant pre-T $\alpha$ chain constituting a pre-TCR that apparently does not recognize any ligands [40], but presumably oligomerizes [41], and signals resulting in important proliferation and progression to the DP cell compartment through DN4 $\left(\mathrm{CD} 4^{-} \mathrm{CD} 8^{-} \mathrm{CD} 44^{-} \mathrm{CD} 25^{-}\right)$cells and an intermediate, immature $\mathrm{SP}\left(\mathrm{CD} 4^{+} \mathrm{CD} 8^{-}\right.$or $\left.\mathrm{CD} 4^{-} \mathrm{CD} 8^{+}\right)$stage $[39,42]$. Then, DP thymocytes that have rearranged mature TCR $\alpha \beta$ receptors are again selected by MHC-peptide complexes presented by cTECs, which have special mechanisms for processing these peptides. In the case of MHCI-peptide complexes, cTECs have thymic proteasomes that contain the $\beta 5$ t protein encoded by Psmb11 gene [43]. Apparently, the $\beta 5$ t protein of thymoproteasomes has lower chymotrypsin activity than the subunits of the immunoproteasomes consequently producing different peptides inside than outside the thymus. Intimate relationship between thymoproteosome activity and positive selection has been demonstrated in Psmb11 $11^{-/}$mice that exhibit significantly reduced proportions of $\mathrm{CD} 4^{-} \mathrm{CD} 8^{+} \mathrm{SP}$ thymocytes and the remaining cells are functionally compromised showing an altered TCR $\alpha \beta$ repertoire [44,45]. In addition, a single-nucleotide polymorphism that produces a thymoproteosome variant (G49s) is associated with the appearance of Sjögren's syndrome and impairs positive selection of $\mathrm{CD} 4^{-} \mathrm{CD} 8^{+}$thymocytes [2].

Similarly, the generation of a proper repertoire of selecting MHCII-associated self-peptides depends on the presence of both a thymus-specific serine protease, TSSP and the lysosomal protease, cathepsin L in cTECs. Accordingly, alterations in any of these proteases impair the positive selection of $\mathrm{CD} 4^{+} \mathrm{CD} 8^{-}$SP cells $[46,47]$.

\section{4. mTECs Constitute A Heterogeneous Thymic Cell Population Involved in both Negative Selection and Treg Cell Generation}

The medulla displays an important array of mTEC subsets whose functions in the thymocyte education has been extensively studied [11,48]. Currently, it is assumed the existence of immature mTECs, mature mTECs implicated in negative selection and the production of Treg cells, and a post mature stage whose functional significance is more controversial.

In addition, mTEPCs seem to be different in embryonic and adult mice. Whereas the former ones include Claudin (Cld) $3 / 4^{\text {hi }}$ progenitor cells, the expression of this cell marker disappears in the postnatal TEPCs, and Cld $3 / 4^{\text {hi }}$ cells seem to be restricted to mature Aire ${ }^{+}$and terminally differentiated mTECs [49]. On the other hand, previous reports classified mTECs into immature $\mathrm{MHCII}{ }^{\mathrm{lo}} \mathrm{CD} 80^{\mathrm{lo}}$ cells $\left(\mathrm{mTEC}^{\mathrm{lo}}\right.$ or mTEC-I) and mature MHCII ${ }^{\text {hi }} \mathrm{CD} 80^{\text {hi }}$ cells (mTEC hi or mTEC-II), but really mTEC ${ }^{\text {lo }}$ cells constitute a heterogeneous cell population that could contain both TEPCs and terminal post-Aire cells [26,50-55]. Therefore, these $\mathrm{mTEC}^{\text {lo }}$ cells presumably consist, at least, of two cell subsets: putative adult mTEPCs, that highly express podoplanin and ligands of CCR7, such as CCL21a, CCL21b, CCL21c [56,57] and predominantly occupy the cortico-medullary border [26,58], and a more mature CCL21-producing mTEC subpopulation involved in the recruitment of positively selected CCR $7^{+}$thymocytes into the medulla [26,57]. Furthermore, Aire ${ }^{+}$terminally differentiated mTECs downregulate their specific cell markers (i.e., Aire, MHCII, and CD80) giving rise to Aire ${ }^{-/ \mathrm{lo}} \mathrm{MHCII}{ }^{\mathrm{lo}} \mathrm{CD} 80^{\mathrm{lo}}$ cells that could be therefore phenotypically considered immature mTECs.

Apart from the upregulation of other cell markers, such as MHCII and CD80 involved in the antigen presentation by mTECs, the most representative marker of the mature mTEC population is the transcription factor Aire. Mature mTEC $^{\text {hi }}$ acquire Aire expression after RANK-RANKL signaling in immature mTECs ${ }^{\text {lo }}$. Thus, mice deficient in RANK or RANKL lack Aire ${ }^{+}$mTECs $^{\text {hi }}$ in the embryonic thymus $[59,60]$. When the deletion of these molecules was tested in neonatal mice, the reduction of 
mTEC hi cells was not complete [61]. In addition, the CD40-mediated effects on mTEC maturation are weaker that those exerted by RANK signals $[60,62]$.

Firstly, Aire was reported as a defective gene product associated with an autoimmune syndrome called autoimmune polyglandular syndrome type 1 (APS1) $[63,64]$. The syndrome coursed with autoimmunity affecting diverse organs [65] and hypersensitivity to mucocutaneous candidiasis associated with autoimmune responses against Th17 cytokines, largely IFN $\alpha$ [66-68].

Aire promotes the expression of thousands of TSAs that govern the deletion of autoreactive T-cells [8,69-71] and the generation of self-reactive Treg cells [72-74]. However, Aire is only expressed in 30\% of mTECs and controls the expression of approximately $40 \%$ of TSAs [12], but the total pool of TSAs expressed in mTECs is highly diverse covering most of the putative self-antigens $[75,76]$. These results suggest that other cells and/or molecules would be implicated in the central tolerance (see below). In fact, the expression of Aire-dependent TSAs is both stochastic and ordered: only a small fraction of mTECs express a specific TSAs and, at the same time, there is a general pattern of multiple co-expression of scarcely related types of TSAs within the individual mTECs [77-79].

Despite the obvious relevance of Aire expression for the establishment of central tolerance, numerous TSAs are expressed in Aire ${ }^{-/-}$mTECs [77,80]. As mentioned above, another transcription factor, Fezf2, has been recently reported for promoting the expression of a second group of TSAs distinct from the Aire-dependent TSAs [81]. Fezf2-deficient mice do not have defects in positive selection but show altered repertoire of $\mathrm{TCR} \mathrm{V}_{\beta}$ in both $\mathrm{CD}^{+}$and $\mathrm{CD} 8^{+} \mathrm{T}$-cells. Additionally, specific elimination of Fezf2 gene in TECs results in autoimmunity with presence of tissue lymphocyte infiltrations and auto-antibodies [12]. Apparently, Aire and Fezf2 genes are controlled independently and do not regulate each other, although recent results indicate that RANK/RANKL signals are key for the appearance of both transcription factors [82]. In any case, only $60 \%$ of TSA genes are regulated by Aire and/or Fezf2 suggesting that there are still other unknown mechanisms for TSA production in the thymus. In this respect, the remaining source of TSAs could be peripheral DCs proposed to transport peripheral TSAs into the thymus and to induce T-cell deletion and Treg cell development [1,83-87]. In addition, mTECs transport self-antigens to intrathymic DCs in an Aire-dependent process $[88,89]$.

Increasing evidence supports that mTEC differentiation continues beyond the Aire ${ }^{+}$stages of thymic epithelium development, to give rise to the so-called tuft cells as well as to terminally differentiated epithelial cells that form a part of the named Hassall's bodies (or corpuscles) [57,90,91]. These terminal epithelial cells express numerous markers of differentiated keratinocytes of the outer epidermal layers, such as keratin 1, keratin 10, involucrins, desmogleins, and Serine protease inhibitor Kazal type 5 (SPINK5) [10]. Whether Aire governs or not this final differentiation of mTECs is a matter of discussion [10]. In addition, the functions of these terminal mTECs are controversial. Although they have lost the MHCII expression making efficient antigen presentation to SP thymocytes difficult, they retain a large fraction of both Aire-dependent and Aire-independent TSA that could transfer to DCs. In addition, human Hassall's bodies, but not murine ones [92], produce Thymus stromal lymphopoietin (TSLP) that induces Foxp3 ${ }^{+}$Treg cells [93].

Tuft cells are neonatal epithelial cells, firstly identified in mucosae [94,95] and later in the thymus $[26,50,96,97]$. Studies of lineage tracing demonstrate that more than half of thymic tuft cells derive from mature $\mathrm{mTECs}^{\text {hi }}$ but the rest do not seem to follow the Aire-expressing cell lineage [26,50]. Furthermore, the genetic signature of thymic tuft cells seems to be unique and, in any case, very different from that of Aire ${ }^{+}$mTECs.

Mucosal tuft cells produce IL25 and express genes involved in the synthesis of acetylcholine, prostaglandins, or leukotrienes, and in the signaling of taste reception, such as Phospholypase $\mathrm{C}$ beta 2 (Plcb2), Transient receptor potential channel subfamily 5 (Trpm5), G protein subunit beta 3 (Gnb3), and $G$ protein subunit gamma 13 (Gng13). Thymic tuft cells also express several members of the taste receptor 2 family as well as L1CAM, DLCK1, MHCII, and CD74, but not other genes characteristic of mucosal tuft cells (i.e., Galectins 2 and 4 (Lgals 2 and Lgals4), Mucin13, Fatty acid binding protein 1 (Fabp1), and Apolipoprotein A1 (Apoa1)) [10]. 
On the other hand, the functions of thymic tuft cells are largely unknown. Studies on tuft cell-deficient thymuses grafted in mice immunized with IL25 indicate that tuft cells are key to prevent the generation of anti-IL25 antibodies [50]. However, thymic tuft cells do not appear to be good APC because they weakly express MHCII. In addition, they could be related to other thymic cell subsets because tuft cell deficiency results in reduced numbers of both NKT2 cells and Eomes ${ }^{+} \mathrm{CD} 8^{+} \mathrm{SP}$ thymocytes [50]. Figure 1 summarizes all these described TECs.

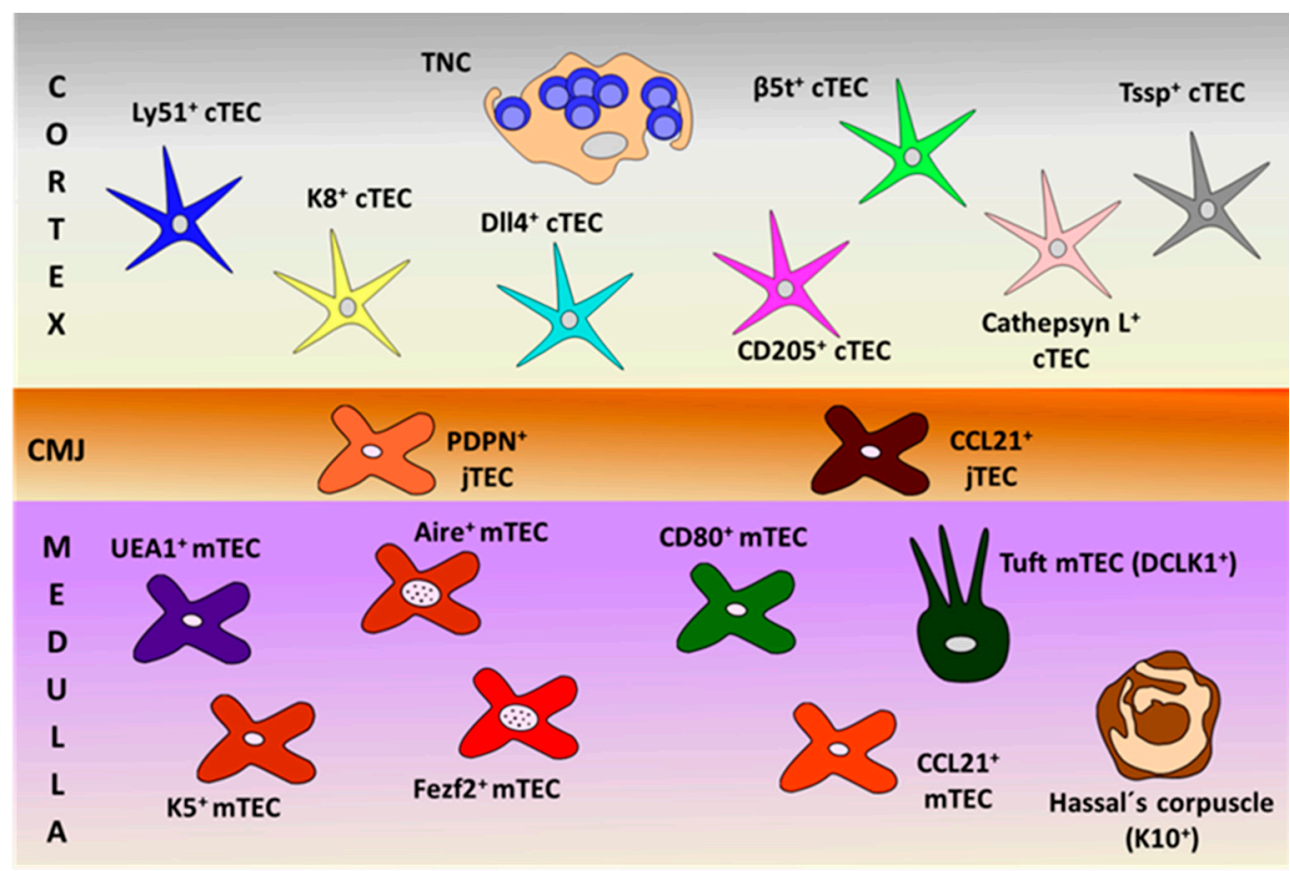

Figure 1. Schematic representation of thymic epithelial cell (TEC) subsets, defined by their specific cell markers in the different thymic compartments (cortex, cortico-medullary junction (CMJ) and medulla). PDPN: podoplanin; TNC: thymic nurse complexes.

\section{The Condition of EphB-Deficient Thymuses}

In the previous sections, we have examined the relevance of distinct TEC populations for the positive and negative selection of developing thymocytes. In general terms, the evidence supports that proper TEC-thymocyte interactions are a requisite for an adequate functional education of thymocytes and for the generation of a proper TCR repertoire. However, we [98] and other authors [82,99-101] have observed studying different experimental models that thymuses showing profound epithelial alterations maintain normal proportions of thymocyte subsets, including positive and negative selected thymocytes, and Treg cells.

Twenty years ago, we demonstrated the expression of erythropoietin-producing hepatocyte (Eph) tyrosine kinase receptors and their ligands, Eph receptor-interacting proteins (ephrins), in the thymus [102], initiating a series of studies on their role in the organ. Particularly, we demonstrated the relevance of EphB2 and EphB3 and their ligands, ephrin-B1 and ephrin-B2, in the organization of a 3D TE network and the establishment of TEC-thymocyte functional interactions [103].

The Eph kinase receptors and their ligands, the ephrins provide positional information and participate in cell-to-cell contacts, cell migration, and cellular attachment/detachment, as well as in cell survival, differentiation, and organogenesis [104,105]. Eph kinases are subdivided in two classes according their molecular structure and sequence identity: A (10 members) and B (6 members). Preferentially, but not exclusively, EphA interact with ephrins-A (6 members) and EphB with ephrin-B (3 members). Remarkably, Eph/ephrin interactions cause bidirectional signaling with forward signaling through Eph and reverse one in those transmitted via ephrins [106]. 
EphB-deficient thymuses, although specific in their phenotypes, show some common features, such as hypocellularity, importantly altered epithelium but few changes in the proportions of thymocyte subsets. In addition, the mutant phenotype becomes evident early in the development but gradually increases in correlation with the establishment of TEC-thymocyte interactions $[98,103]$.

Mutant thymuses have lower numbers of both thymocytes [107,108] and TECs [109,110]. Moreover, they are colonized in vitro [111] and in vivo $[108,112]$ by lower numbers of recent lymphoid emigrants that, in addition, mature slower than the WT ones in correlation with a low production of chemokines by mutant TECs [111]. Increased proportions of apoptotic thymocytes and reduced percentages of cycling cells [107] also contribute to the lymphoid hypocellularity of EphB-deficient thymuses. These reduced proportions of dividing thymocytes could be related to diminished production of Dll4 and/or diminished IL7 receptor $\alpha$ chain transcripts [110], a finding also reported in the thymocytes specifically deleted of ephrin-B1 and/or ephrin-B2 genes [113].

This pattern of thymocyte development correlates with a similar behavior of mutant TECs, such as the decreased proportions of immature MTS20 ${ }^{+}$cells reflect [108], their delayed maturation and the reduced total TEC numbers. Moreover, the mutant thymi show reduced proportions of cycling TECs due to both the reduced number of seeding lymphoid progenitors into the thymus $[108,110]$ and lower numbers of transcripts of FGF and its receptor FGFR2iiib [110], both molecules involved in epithelial cell proliferation $[100,114]$. On the other hand, increased percentages of both fetal and neonatal apoptotic TECs [115] also contribute to the reduced cell content of EphB-deficient thymuses.

The histological organization of EphB-deficient thymuses is also severely altered. Murine WT thymic medulla is formed by small, scattered foci that expand and converge after birth [116], but in adult mutant thymuses, particularly in the EphB2-/- ones, the fusion in a unique medulla is impaired and the small, isolated epithelial islets remain [109]. In support, reaggregate thymus organ cultures (RTOC) established either with EphB2 $2^{-/}$or EphB3 ${ }^{-/-}$thymic lobes or with WT ones treated either with blocking anti-EphB2 or anti-EphB3 antibodies show more and smaller medullary foci as compared with untreated WT RTOCs [117].

In addition, in many thymic areas, thymocytes and TECs are physically isolated because EphB2 ${ }^{-/-}$ TECs exhibit shortened cell processes or a lack of them, as in the EphB3 ${ }^{-/}$ones [109]. Similar phenotypes occur in RTOCs derived from WT thymi treated with blocking anti-EphB2 or anti-EphB3 antibodies [98]. Obviously, these changes together with the abovementioned increased numbers of apoptotic TECs, prevent the proper TEC-thymocyte interactions, essential for thymocyte selection, and favor the appearance of epithelial free areas (EFAs) [118].

On the other hand, the lack of EphB, particularly EphB3, results in delayed cTEC maturation from the earliest stages of development [110]. Thus, E14.5 and E15.5 mutant thymuses accumulate immature $\mathrm{Ly}_{51} 1^{+} \mathrm{CD} 205^{-}$CTEC, whereas the proportions of mature $\mathrm{Ly} 51^{+} \mathrm{CD} 205^{+}$cells decrease. The evolution of other CTEC subsets identified by other cell markers, such as CD40 and MHCII, follows the same pattern. Remarkably, the proportions of $\beta 5 \mathrm{t}^{+}$cTECs involved in antigen processing and presentation via $\mathrm{MHCI}$ molecules to DP thymocytes is also significantly reduced in mutant embryonic thymuses [110]. On the contrary, the most important alterations of the medulla occur when EphB2 is lacking. These animals show delayed TEC development that courses with accumulation of Cld $3,4^{\text {hi }}$ SSEA $1^{+}$TEPCs and, consequently, with a decrease in mature mTECs. Proportions of Aire ${ }^{+}$ cells are also significantly reduced in both mutant postnatal thymuses [117].

Although little is known on the molecules that regulate the thymic cortical epithelium, in the medulla, molecules of the TNF/TNFR family, and particularly the RANK/RANKL pair are important $[24,59,60,119]$ although other members, such as osteoprotegerin [61] and LT $\beta R$ [120] might modulate their effects [121]. Although in EphB-deficient fetal and postnatal mice we did not see changes in the expression of both RANK and LT $\beta R$ transcripts, they exhibited decreased proportions of the E15.5 RANKL ${ }^{+} \mathrm{V} \gamma 5^{+}$thymocytes. This reduction and/or just a partial reduction of cell-to-cell interactions between these lymphoid cells and the mTECs could explain the alterations observed in mutant thymi, particularly the reduction of Aire ${ }^{+}$mTECs, profoundly affected in the absence of 
RANK/RANKL signaling [60,61]. Indeed, the defective maturation of mutant mTEC is recovered after supply of agonist anti-RANK antibodies for 4 days. Accordingly, the lack of EphB affects the intimate molecular machinery governing mTEC maturation [117].

Despite the important alterations undergone by the epithelial component, the EphB-deficient thymi show little changes in the thymocyte phenotype. Although, as mentioned above, reduced percentages of lymphoid progenitor cells seed the mutant thymi, there are no significant changes in the percentages of distinct thymocyte subsets subsequently [98], except for a slight increase of DN1 $\left(\mathrm{CD} 4^{-} \mathrm{CD} 8^{-} \mathrm{CD} 44^{+} \mathrm{CD} 25^{-}\right)$cell proportions and reduced DN3 thymocytes $[107,108]$, and increased proportions of $\mathrm{V} \beta 3 \mathrm{CD} 4^{+}$cells that suggest certain altered thymocyte selection. On the contrary, there were no differences between mutant and WT thymuses in the proportions of neither positive selected thymocytes or negative selected cells, nor in the percentage of total thymic Treg cells. In addition, in the periphery no changes occur in the proportions of Th1, Th2, and Th17 [98], and the percentage of Treg remains unchanged in the spleen but increases slightly in mutant inguinal lymph nodes (ILNs), as compared with WT values [98]. These results have been recently confirmed (Figures 2 and 3).
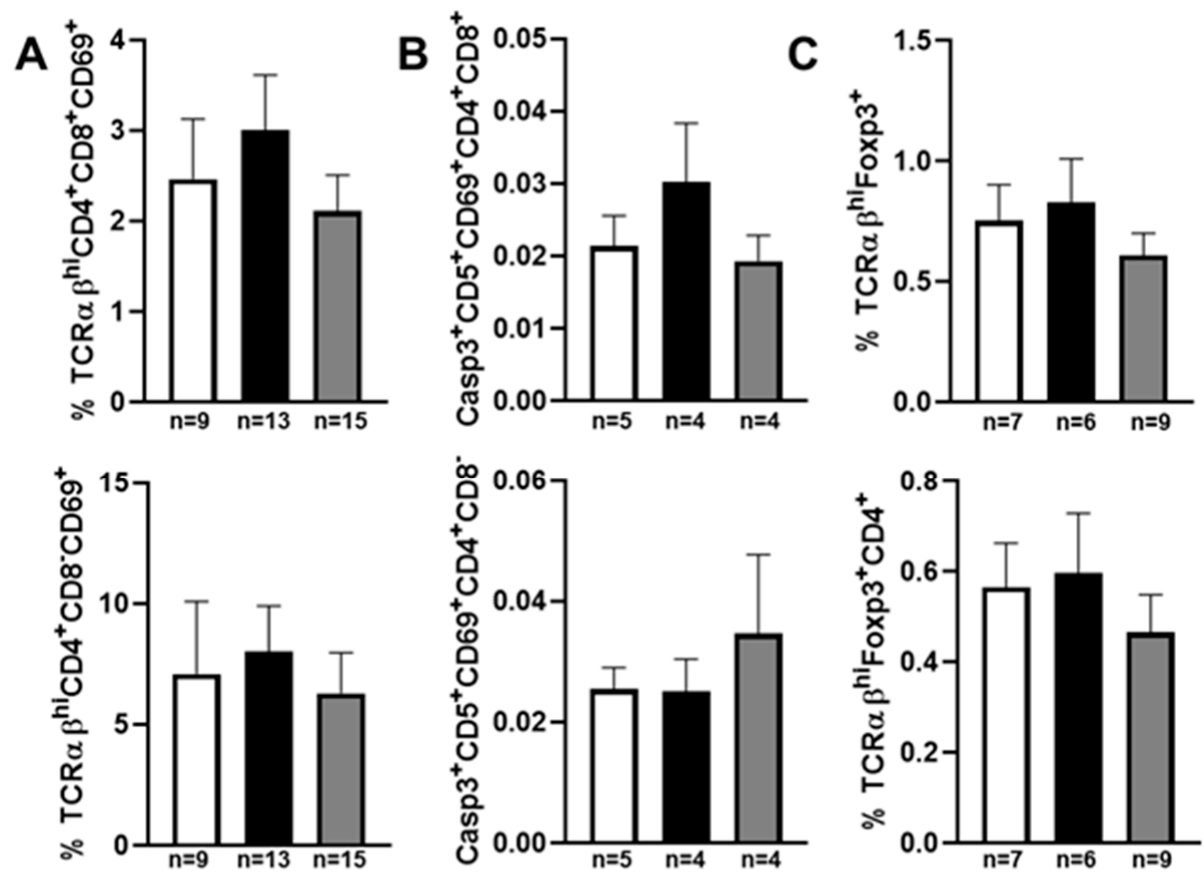

$\square$ WT $\square$ EphB2-/- $\square$ EphB3-/-

Figure 2. Percentages of positive and negative selected T-cells and T regulatory (Treg) cells in the thymus of EphB-deficient mice. Proportions of positive selected TCR $\alpha \beta^{\text {hi }} \mathrm{CD} 4^{+} \mathrm{CD} 8^{+} \mathrm{CD} 69^{+}$and $\mathrm{TCR} \alpha \beta^{\text {hi }} \mathrm{CD} 4^{+} \mathrm{CD} 8^{-} \mathrm{CD} 69^{+}$thymocytes (A), negative selected Casp3 ${ }^{+} \mathrm{CD} 5^{+} \mathrm{CD} 69^{+} \mathrm{CD} 4^{+} \mathrm{CD} 8^{+}$cells and $\mathrm{Casp}^{+} \mathrm{CD}^{+} \mathrm{CD} 9^{+} \mathrm{CD} 4^{+} \mathrm{CD} 8^{-}$cells (B), and total TCR $\alpha \beta^{\text {hi }} \mathrm{Foxp}^{+}$and TCR $\alpha \beta^{\text {hi }} \mathrm{Foxp}^{+} \mathrm{CD} 4^{+}$ thymic Treg cells $(\mathbf{C})$. Non-significant differences were found between WT and mutant values following the one-way ANOVA test with Tukey post hoc test. Caspase3 (Casp3). n, number of studied animals. 

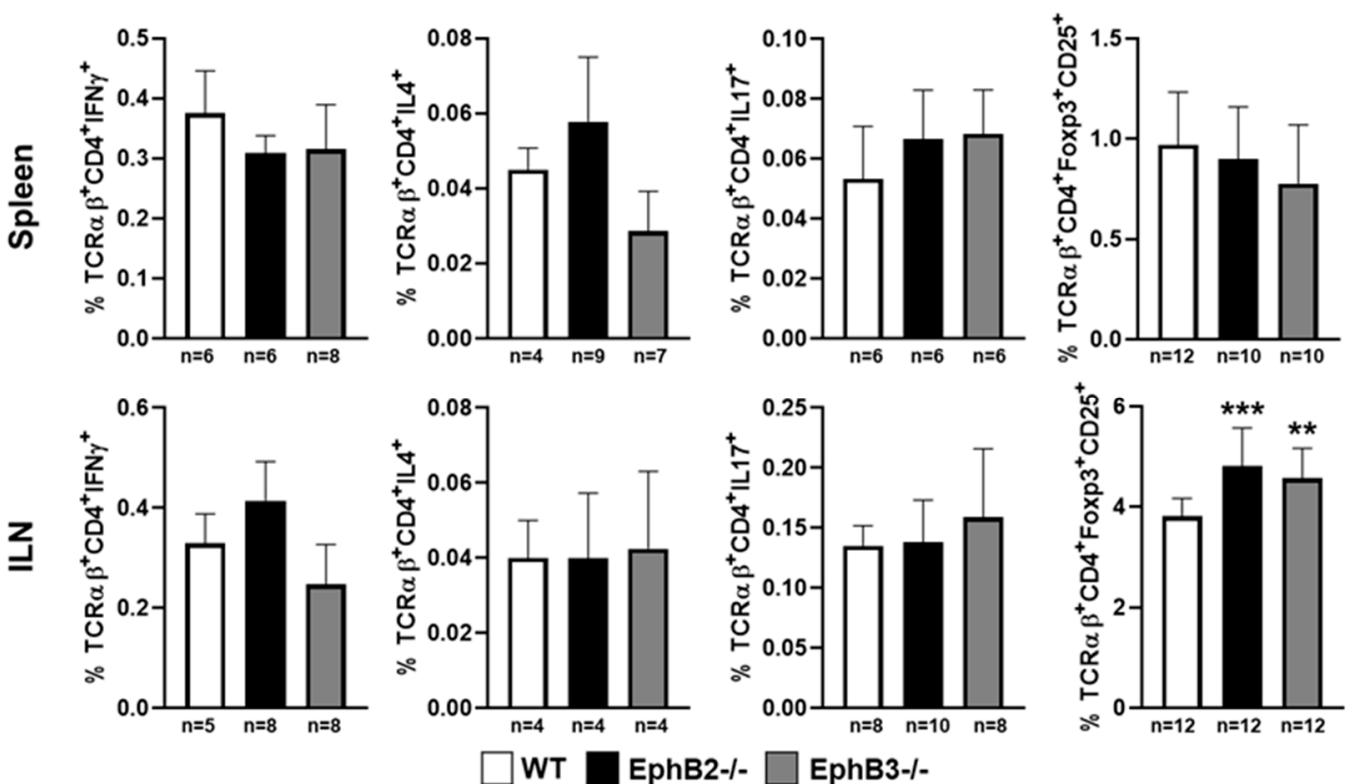

Figure 3. Proportions of Th1 $\left(\mathrm{TCR} \alpha \beta^{+} \mathrm{CD} 4^{+} \mathrm{IFN} \gamma^{+}\right)$, Th2 $\left(\mathrm{TCR} \alpha \beta^{+} \mathrm{CD} 4^{+} \mathrm{IL} 4^{+}\right)$, Th17 $\left(\mathrm{TCR} \alpha \beta^{+} \mathrm{CD} 4^{+} \mathrm{IL}_{17}{ }^{+}\right)$lymphocytes, and Treg cells (TCR $\alpha \beta^{+} \mathrm{CD} 4^{+} \mathrm{CD} 25^{+}$FoxP3 $\left.{ }^{+}\right)$in both spleen and inguinal lymph nodes (ILN) in EphB-mutant mice. The significance of the one-way ANOVA test with Tukey post hoc test between WT and mutant values is indicated as: ${ }^{* *} p<0.01$; ${ }^{* * *} p<0.001$. $n$, number of studied animals.

\section{Does the Lack of Eph and/or Ephrins Affect the Thymic Selection?}

At first glance, we might think that Eph and/or ephrins could directly affect the central tolerance. In this respect, the available data are very limited and contradictory. No changes in the T-cell maturation have been reported in mice with conditionally deleted EphB4 gene in TECs [122], deficiency in EphB6 [123] or in four Ephs together, EphB1, EphB2, EphB3, and EphB6 [124]. In addition, the deletion of ephrin-B1 or ephrin-B2 in thymocytes does not induce thymus phenotypes $[125,126]$, but the absence of the two ephrins alters thymocytes and thymic structure [127] and induces low sensitivity to distinct autoimmune models $[127,128]$. We also reported reduced proportions of positive selected $\mathrm{TCR} \alpha \beta^{\text {hi }} \mathrm{CD} 69^{+}$thymocytes in some mice with ephrin-B1 and/or ephrin-B2 deleted in TECs [35] and EphA4-deficient thymuses show reduced percentages of both DP TCR $\alpha \beta^{\text {hi }}$ cells and CD69+ cells [129].

Another possibility is to consider that EphB affects thymus phenotype via thymocyte-TEC interactions or through molecules involved in the generation of functional thymocytes. It is difficult to explain how the described alterations in thymic epithelial network do not impair, partially at least, the thymocyte development. Remarkably, altered thymic architecture has been associated with autoimmunity [130]. For example, individuals with Down's syndrome have altered thymic histological organization and cell content and frequently develop autoimmune diseases by breakdown of central tolerance [131].

The so-called thymic nurse complexes (TNC), where single cTECs intimately interact with 5-30 thymocytes governing their secondary TCR $\alpha$ chain rearrangements, are a good experimental model to analyze the thymocyte-TEC interactions occurring in the thymic cortex [132]. Recently, we demonstrated that TNCs derived from EphB-deficient thymuses yielded fewer complexes due to the reduction of the numbers of TNCs containing 6-10 thymocytes, the most frequent in WT thymuses, but there were no changes in the proportions of positive selected TCR $\alpha \beta^{\text {hi }} \mathrm{CD} 69^{+}$thymocytes [98]. In addition, the number and establishment of cell conjugates between TECs and DP thymocytes are altered when established with mutant DP cells [133].

These results are important because they question whether the observed defects in EphB mutant thymuses are really sufficient to impair the functional properties of thymocytes. A similar conclusion can 
be reached when considering the alterations in the expression of several molecules in the EphB-deficient thymuses. According to our results, the expression of numerous molecules involved in the functional interactions between TECs and thymocytes (i.e., Dll4, IL7/IL7R, $\beta 5 t$, Aire, RANK/RANKL, MHCII, $\mathrm{CD} 80$ ) are importantly reduced in mutant thymuses. Why do these changes not result in altered positive and/or negative selection of thymocytes? In other models, decreased Aire expression predisposes to autoimmunity $[134,135]$.

Other possibilities are that either other cells implicated in thymocyte education, largely DCs, can partially reinforce the reduced activity of TECs or that just a few unaltered areas of thymic stroma are sufficient to support a fairly normal T-cell development $[82,99,100]$.

As mentioned above, DCs participate in the elimination of self-reactive thymocytes and the formation of Treg cells by transporting peripheral TSA into the thymus $[1,84,85]$ or after peripheral tissue antigens (PTA) transfer from mTECs [136-138]. Although we have no data on the percentages of DCs in EphB-deficient thymi, in EphA4 $4^{-/}$mice, whose thymi show also profound epithelial alterations, there were no changes in DC proportions (Data not shown).

\section{How Many TECs Are Necessary for Supporting a Proper T-Cell Maturation?}

With respect to the possibility that a few thymic areas could be sufficient to ensure proper thymocyte maturation, we analyze the thymocyte differentiation in thymic cell reaggregates organized from different numbers of thymic stromal cells (TSC, $1-0.085 \times 10^{6}$ cells) grafted under the kidney capsule of FoxN1 ${ }^{-/-}$mice. Reaggregates (RTOCs) had been established from E14.5 WT thymic lobes treated with 2'-dGuo for 7 days to eliminate thymocytes and, in general, any dividing thymic cells (Figure 4A). One month after grafting, thymic reaggregates as well as FoxN1 ${ }^{-1-}$ spleen and ILNs were isolated and their lymphoid cell subsets examined by flow cytometry. Only those reaggregates that importantly grew after grafting were evaluated; nevertheless, the obtained results must be considered preliminary because of the low numbers of aggregates that we have been capable to analyze and some experiments have not been performed due to technical problems in our animal facilities.

A

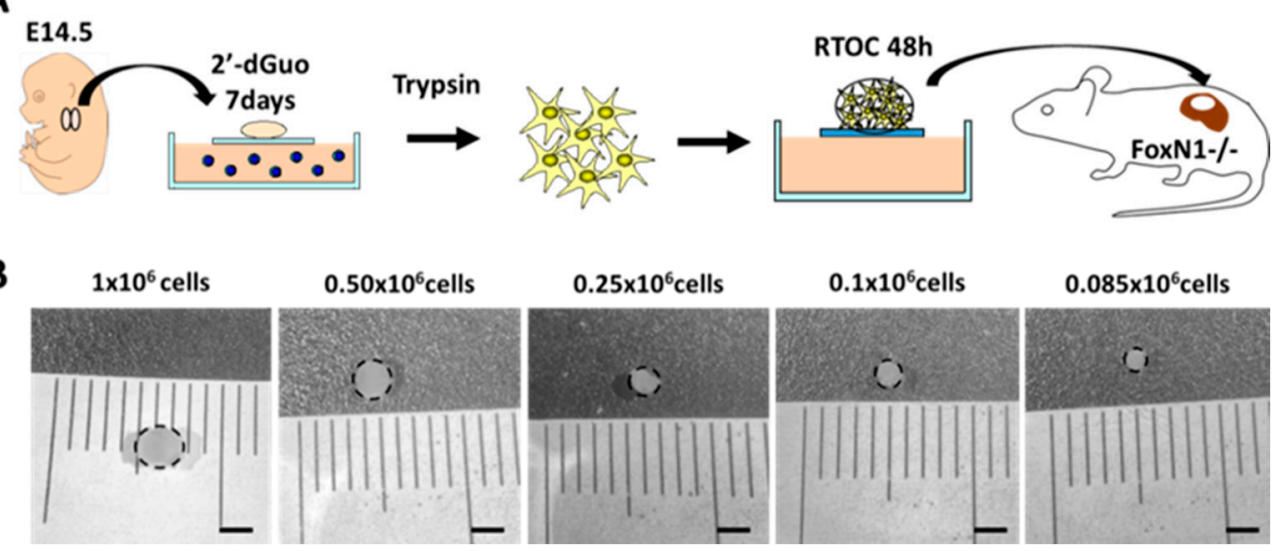

Figure 4. Diagram of reaggregate thymus organ culture (RTOC) establishment and representative images of the yielded thymi one month after grafting under the kidney capsule of FoxN1 ${ }^{-/-}$mice. (A) E14.5 WT thymic fetal lobes were treated with 2'-dGuo. After 7 days, thymic lobes containing just stromal cells were disaggregated with trypsin and reaggregated (RTOC) using different cell numbers $\left(1,0.5,0.25,0.1\right.$, and $0.085 \times 10^{6}$ cells $)$ and cultured for $48 \mathrm{~h}$. Then, RTOCs were grafted under the kidney capsule of FoxN1 ${ }^{-/-}$mice for 1 month. (B) Representative RTOCs recovered one month after grafting. Notice the gradual reduction in the lobe size as compared with control RTOCs $\left(1 \times 10^{6}\right.$ cells $)$. Dotted line marks the limits of RTOC. Scale bar: $2 \mathrm{~mm}$.

Gross-anatomy of grafted one-month-old RTOCs confirmed that reaggregates established with higher numbers of thymic stromal cells produced both larger sized-thymic lobes (Figure 4B) and higher 
numbers of yielded thymic cells (Table 1). Thus, RTOCs established from $1-0.5 \times 10^{6}$ stromal cells grew in vivo around 5-7 times, one month after grafting under the kidney capsule of FoxN1 $1^{-/}$mice (Table 1 ). On the contrary, when RTOCs formed with lower numbers of stromal cells $\left(0.25-0.085 \times 10^{6}\right.$ cells $)$ were used, the number of yielded thymic cells was significantly lower (Table 1 ) and the observed growth one month later was around 3-4 times.

Table 1. Cellularity and proportions of thymocyte subsets.

\begin{tabular}{|c|c|c|c|c|c|}
\hline RTOC $\left(\times 10^{6}\right.$ TSC $)$ & $\begin{array}{l}\text { After Graftment } \\
\left(\times 10^{6} \text { cells }\right)\end{array}$ & $\begin{array}{c}\% \mathrm{CD}^{+} \\
\left(\mathrm{CD}^{+} \mathrm{CD}^{-}\right)\end{array}$ & $\begin{array}{c}\% \text { DP } \\
\left(\mathrm{CD}^{+} \mathrm{CD8}^{+}\right)\end{array}$ & $\begin{array}{c}\% \mathrm{DN} \\
\left(\mathrm{CD}^{-} \mathrm{CD}^{-}\right)\end{array}$ & $\begin{array}{c}\% \mathrm{CD}^{+} \\
\left(\mathrm{CD}^{-} \mathrm{CD8}^{+}\right)\end{array}$ \\
\hline 1 & $5.05 \pm 2.71$ & $7.00 \pm 2.27$ & $87.95 \pm 2.26$ & $2.11 \pm 0.10$ & $2.94 \pm 0.21$ \\
\hline 0.5 & $3.54 \pm 2.41$ & $8.94 \pm 0.68$ & $87.56 \pm 0.59$ & $1.00 \pm 0.43$ & $2.51 \pm 0.85$ \\
\hline 0.25 & $1.03 \pm 0.70$ & $10.24 \pm 1.50$ & $84.24 \pm 2.17$ & $2.08 \pm 0.26$ & $3.45 \pm 0.41$ \\
\hline 0.1 & $0.34 \pm 0.18^{*}$ & $8.96 \pm 3.59$ & $86.24 \pm 5.46$ & $3.11 \pm 2.23$ & $1.70 \pm 1.01$ \\
\hline 0.085 & $0.26 \pm 0.23 *$ & $16.44 \pm 3.80 *$ & $76.49 \pm 4.11 *$ & $2.36 \pm 0.78$ & $4.72 \pm 1.81$ \\
\hline
\end{tabular}

Data show the number of cells and the proportions of thymocyte subsets according to CD4/CD8 expression in RTOCs established with different numbers of thymic stromal cells $\left(1,0.5,0.25,0.1\right.$, and $\left.0.085 \times 10^{6}\right)$ after one month of engraftment under the kidney capsule of FoxN1 $1^{-/-}$mice. The significance of the one-way ANOVA test with Dunnett post hoc test comparing with control RTOC $\left(1 \times 10^{6}\right.$ cells $)$ is indicated as: ${ }^{*} p<0.05$. Number of studied RTOCs, $n=3$.

These variations in the amount of yielded thymic cells correlated well with changes in the proportions of the most numerous thymocyte subsets, DP cells and TCR $\alpha \beta^{\text {hi }} \mathrm{CD} 4^{+}$cells (Tables 1 and 2). Whereas RTOCs constituted with $1 \times 10^{6}$ thymic stromal cells showed normal proportions of the distinct thymocyte subsets, quite similar to those reported in 2-month-old adult thymi [139], in RTOCs established with lower numbers of cells, there were some alterations in the T-cell maturation (although not statistically significant) consisting in gradual decreased frequencies of DP cells (Table 1) and increased percentages of TCR $\alpha \beta^{\text {hi }}$ thymocytes, largely TCR $\alpha \beta^{\text {hi }} C D 4^{+}$T-cells (Table 2 ). This altered pattern of T-cell differentiation was particularly evident in grafted RTOCs formed with $0.085 \times 10^{6}$ cells, in which the found values were statistically significant as compared to grafted RTOCs formed with $1 \times 10^{6}$ stromal cells (Tables 1 and 2). In periphery, preliminary results demonstrated a similar condition with reduced proportions of TCR $\alpha \beta^{\text {hi }}$ T lymphocytes in both spleen and ILNs of FoxN1 $1^{-/-}$mice four months after to be grafted with RTOCs initially containing $0.1 \times 10^{6}$ thymic stromal cells. In any experimental situation, FoxN1 ${ }^{-/-}$spleen or lymph nodes did not contain $\mathrm{T}$ lymphocytes one month after grafting, apart from those always present in non-grafted FoxN1 $1^{-/}$peripheral lymphoid organs (Data not shown).

Table 2. Proportions of mature TCR $\alpha \beta^{\text {hi }}$ thymocytes.

\begin{tabular}{|c|c|c|c|c|}
\hline $\begin{array}{l}\text { RTOC }\left(\times 10^{6}\right. \\
\text { TSC })\end{array}$ & $\begin{array}{l}\% \text { of Total } \\
\text { TCR } \alpha \beta^{\text {hi }}\end{array}$ & $\begin{array}{c}\% \text { of Total } \\
\text { TCR } \alpha \beta^{\text {hi }} \text { CD } 4^{+}\end{array}$ & $\begin{array}{c}\% \text { of Total } \\
\text { TCR } \alpha \beta^{\text {hi }} \text { CD }^{+}\end{array}$ & $\begin{array}{c}\% \text { of Total } \\
\mathrm{TCR} \alpha \beta^{\mathrm{hi}} \mathrm{CD} 4^{+} \mathrm{CD} 8^{+}\end{array}$ \\
\hline 1 & $9.20 \pm 3.09$ & $5.51 \pm 1.96$ & $1.36 \pm 0.37$ & $2.11 \pm 0.72$ \\
\hline 0.5 & $11.03 \pm 1.01$ & $7.05 \pm 0.46$ & $1.57 \pm 0.07$ & $2.30 \pm 0.50$ \\
\hline 0.25 & $13.17 \pm 0.93$ & $8.38 \pm 0.97$ & $1.93 \pm 0.54$ & $2.38 \pm 0.47$ \\
\hline 0.1 & $9.49 \pm 3.83$ & $5.73 \pm 2.42$ & $1.15 \pm 0.66$ & $1.94 \pm 0.15$ \\
\hline 0.085 & $20.76 \pm 3.53^{* *}$ & $14.00 \pm 3.21^{* *}$ & $3.11 \pm 0.67 *$ & $3.31 \pm 0.44$ \\
\hline
\end{tabular}

Proportions of total TCR $\alpha \beta^{\text {hi }}$ cells and total TCR $\alpha \beta^{\text {hi }} \mathrm{CD} 4^{+}, \mathrm{TCR} \alpha \beta^{\text {hi }} \mathrm{CD} 8^{+}$, and $\mathrm{TCR} \alpha \beta^{\text {hi }} \mathrm{CD} 4^{+} \mathrm{CD} 8^{+}$cells yielded by the different RTOCs one month after grafting. The significance of the one-way ANOVA test with Dunnett post hoc test comparing with control RTOC $\left(1 \times 10^{6}\right.$ cells $)$ is indicated as: ${ }^{*} p<0.05 ;{ }^{* *} p<0.01$. Number of studied RTOCs, $n=3$.

On the other hand, RTOCs containing the lowest numbers of thymic stromal cells showed significantly lower proportions of positively selected $\mathrm{CD} 69^{+}$cells within the TCR $\alpha \beta^{\text {hi }}$ cell population that principally corresponded to the TCR $\alpha \beta^{\text {hi }} \mathrm{CD} 4^{+}$cell subset (Table 3 ). However, the high percentage of the TCR $\alpha \beta^{\text {hi }}$ cells occurring in these grafted RTOCs resulted in no significant differences with respect 
to the values observed in grafted RTOCs established with $1 \times 10^{6}$ cells, when the total proportions of both thymic TCR $\alpha \beta^{\text {hi }} \mathrm{CD} 69^{+}$cells and TCR $\alpha \beta{ }^{\text {hi }} \mathrm{CD} 69^{+} \mathrm{CD} 4^{+}$cells were evaluated (Table 3).

Table 3. Proportions of positive selected thymocytes.

\begin{tabular}{|c|c|c|c|c|}
\hline RTOC $\left(\times 10^{6}\right.$ TSC $)$ & $\begin{array}{c}\% \text { of } \mathrm{CD}^{6} 9^{+} \text {within } \\
\text { TCR } \alpha \beta^{\text {hi }} \text { Cells }\end{array}$ & $\begin{array}{l}\% \text { of CD69 } 9^{+} \text {within } \\
\text { CD4 }^{+} \text {Gated in } \\
\text { TCR } \alpha \beta^{\text {hi Cells }}\end{array}$ & $\begin{array}{c}\% \text { of Total } \\
\text { TCR } \alpha \beta^{\text {hi }} \text { CD } 69^{+}\end{array}$ & $\begin{array}{c}\% \text { of Total } \\
\text { TCR } \alpha \beta^{\text {hi }}{\text { CD } 69^{+}}^{+} \mathrm{CD} 4^{+}\end{array}$ \\
\hline 1 & $55.06 \pm 4.98$ & $59.19 \pm 5.23$ & $4.76 \pm 1.51$ & $3.13 \pm 1.09$ \\
\hline 0.5 & $49.84 \pm 8.53$ & $53.23 \pm 9.16$ & $5.42 \pm 0.02$ & $3.62 \pm 0.45$ \\
\hline 0.25 & $46.62 \pm 4.69$ & $50.22 \pm 1.46$ & $6.99 \pm 2.23$ & $4.85 \pm 1.65$ \\
\hline 0.1 & $45.45 \pm 8.40$ & $47.05 \pm 12.12$ & $4.51 \pm 1.11$ & $2.92 \pm 1.06$ \\
\hline 0.085 & $39.02 \pm 3.75^{*}$ & $37.72 \pm 3.62 *$ & $8.49 \pm 2.73$ & $5.48 \pm 2.18$ \\
\hline
\end{tabular}

Data show the proportions of CD $69^{+}$cells within the total TCR $\alpha \beta^{\text {hi }}$ cells and in the CD4 $4^{+}$cell population gated in TCR $\alpha \beta^{\text {hi }}$ cells. Proportions of total TCR $\alpha \beta^{\text {hi }} \mathrm{CD} 69^{+}$and TCR $\alpha \beta^{\text {hi }} \mathrm{CD} 69^{+} \mathrm{CD} 4^{+}$cells yielded by the different grafted RTOCs are also indicated. The significance of the one-way ANOVA test with Dunnett post hoc test comparing with control RTOC $\left(1 \times 10^{6}\right.$ cells $)$ is indicated as: ${ }^{*} p<0.05$. Number of studied RTOCs, $n=3$.

A quite similar condition was observed when the proportion of Treg cells was examined in the distinct grafted RTOCs (Table 4). Remarkably, there were no significant differences in the proportions of Foxp $3^{+}$Treg cells into the TCR $\alpha \beta^{\text {hi }}$ cell compartment between grafted RTOCs generated with distinct numbers of TSC. However, in those grafted RTOCs initiated with the lowest numbers of stromal cells $\left(0.085 \times 10^{6}\right.$ cells $)$, because they contain a high number of TCR $\alpha \beta^{\text {hi }}$ cells, the proportions of both total $\mathrm{TCR} \alpha \beta{ }^{\text {hi }}{ }^{\mathrm{Foxp}} 3^{+}$Treg cells and TCR $\alpha \beta^{\text {hi }}{ }^{\mathrm{Foxp}} 3^{+} \mathrm{CD} 4^{+}$cells significantly increased with respect to the values observed in the other grafted RTOCs (Table 4). Unfortunately, we have currently no reliable data on the condition of negative selected thymocytes due to problems with the number of available embryonic mice.

Table 4. Proportions of T regulatory cells (Treg).

\begin{tabular}{|c|c|c|c|c|}
\hline RTOC $\left(\times 10^{6}\right.$ TSC) & $\begin{array}{l}\% \text { of Foxp } 3^{+} \text {within } \\
\text { TCR } \alpha \beta^{\text {hi }} \text { Cells }\end{array}$ & $\begin{array}{c}\text { \% of Foxp3 } 3^{+} \text {within } \\
\mathrm{CD}^{+} \text {Gated in } \\
\text { TCR } \alpha \beta^{\text {hi Cells }}\end{array}$ & $\begin{array}{c}\text { \% of Total } \\
\text { TCR } \alpha \beta^{\text {hi Foxp } 3^{+}}\end{array}$ & $\begin{array}{c}\% \text { of Total } \\
\text { TCR } \alpha \beta^{\text {hi }}{\text { Foxp } 3^{+} \text {CD } 4^{+}}^{+}\end{array}$ \\
\hline 1 & $3.24 \pm 0.12$ & $3.63 \pm 0.39$ & $0.25 \pm 0.07$ & $0.18 \pm 0.05$ \\
\hline 0.5 & $3.73 \pm 1.29$ & $4.47 \pm 1.68$ & $0.36 \pm 0.15$ & $0.28 \pm 0.10$ \\
\hline 0.25 & $2.64 \pm 0.58$ & $3.04 \pm 0.71$ & $0.30 \pm 0.04$ & $0.25 \pm 0.03$ \\
\hline 0.1 & $3.24 \pm 0.23$ & $3.64 \pm 0.13$ & $0.23 \pm 0.01$ & $0.15 \pm 0.01$ \\
\hline 0.085 & $3.46 \pm 1.52$ & $4.06 \pm 2.25$ & $0.57 \pm 0.15^{*}$ & $0.44 \pm 0.12 *$ \\
\hline
\end{tabular}

Data show the FoxP3 expression in the total TCR $\alpha \beta^{\text {hi }}$ cells and in $\mathrm{CD} 4^{+}$cell subset gated in TCR $\alpha \beta^{\text {hi }}$ cells. Proportions of total Treg (TCR $\left.\alpha \beta^{\text {hi }} \mathrm{Foxp}^{+}\right)$and TCR $\alpha \beta^{\text {hi }} \mathrm{Foxp} 3^{+} \mathrm{CD} 4^{+}$cells are also indicated. The significance of the one-way ANOVA test with Dunnett post hoc test comparing with control RTOC $\left(1 \times 10^{6}\right.$ cells $)$ is indicated as: * $p<0.05$. Number of studied RTOCs, $n=3$.

In agreement with these results, previous studies using different experimental approaches determined a close relationship between the numbers of TECs and total thymocyte numbers $[140,141]$. These studies remarked also that, although the TEC numbers decreased 4 times, there were no changes in the proportions of distinct T-cell subsets. Thus, a low number of TECs would support normal T-cell differentiation, as also indicated in our current results in which a reduction of 10 or more times of thymic stromal cells in the initial RTOCs is necessary for observing significant alterations of the maturation of T-cell subpopulations. All together, these results confirm our hypothesis that a low number of TECs can be sufficient for a proper T-cell differentiation; only below that number it is impossible to have a normal $\mathrm{T}$ lymphopoiesis, but the proportions of both positively selected thymocytes and Treg cells appear to be normal. Functional studies in progress and determination of the proportions of negatively selected thymocytes will confirm or refute definitively the immunological significance of these preliminary results. 
Author Contributions: Investigation, J.G.-C. and S.M.-H.; formal analysis, J.G-C., S.M.-H., and A.G.Z.; writing-original draft preparation, A.G.Z.; writing—review and editing, J.G.-C., S.M.-H., and A.G.Z.; funding acquisition, A.G.Z. All authors have read and accepted the published version of the manuscript.

Funding: This research was funded by the Spanish Ministry of Science, Innovation and Universities (RTI2018-093938-B-I00), the Carlos III Health Institute (RD16/0011/0002, Cell Therapy Network, TERCEL) and the Regional Government of Madrid (S2017/BMD-3692, Avancell).

Acknowledgments: We thank the Cytometry and Fluorescence Microscopy and Animal Housing Centers of Complutense University for the use of their facilities.

Conflicts of Interest: The authors declare no conflict of interest.

\section{References}

1. Gallegos, A.M.; Bevan, M.J. Central tolerance to tissue-specific antigens mediated by direct and indirect antigen presentation. J. Exp. Med. 2004, 200, 1039-1049. [CrossRef] [PubMed]

2. Cheng, M.; Anderson, M.S. Thymic tolerance as a key brake on autoimmunity. Nat. Immunol. 2018, 19, 659-664. [CrossRef] [PubMed]

3. Dominguez-Villar, M.; Hafler, D.A. Regulatory T cells in autoimmune disease. Nat. Immunol. 2018, 19, 665-673. [CrossRef] [PubMed]

4. Munoz, J.J.; Zapata, A.G. Thymus ontogeny and development. In Thymus Transcriptome and Cell Biology; Passos, G.A., Ed.; Springer: Cham, Switzerland, 2019; pp. 19-34.

5. Passos, G.A.; Genari, A.B.; Assis, A.F.; Monteleone-Cassiano, A.C.; Donadi, E.A.; Oliveira, E.H.; Duarte, M.J.; Machado, M.V.; Tanaka, P.P.; Mascarenhas, R. The thymus as a mirror of the body's gene expression. In Thymus Transcriptome and Cell Biology; Passos, G.A., Ed.; Springer: Cham, Switzerland, 2019; pp. 215-234.

6. Singer, A.; Adoro, S.; Park, J.H. Lineage fate and intense debate: Myths, models and mechanisms of CD4versus CD8-lineage choice. Nat. Rev. Immunol. 2008, 8, 788-801. [CrossRef]

7. Forster, R.; Davalos-Misslitz, A.C.; Rot, A. CCR7 and its ligands: Balancing immunity and tolerance. Nat. Rev. Immunol. 2008, 8, 362-371. [CrossRef] [PubMed]

8. Derbinski, J.; Schulte, A.; Kyewski, B.; Klein, L. Promiscuous gene expression in medullary thymic epithelial cells mirrors the peripheral self. Nat. Immunol. 2001, 2, 1032-1039. [CrossRef]

9. Abramson, J.; Anderson, G. Thymic epithelial cells. Annu. Rev. Immunol. 2017, 35, 85-118. [CrossRef]

10. Kadouri, N.; Nevo, S.; Goldfarb, Y.; Abramson, J. Thymic epithelial cell heterogeneity: TEC by TEC. Nat. Rev. Immunol. 2020, 20, 239-253. [CrossRef]

11. Wang, H.X.; Pan, W.; Zheng, L.; Zhong, X.P.; Tan, L.; Liang, Z.; He, J.; Feng, P.; Zhao, Y.; Qiu, Y.R. Thymic epithelial cells contribute to thymopoiesis and T cell development. Front. Immunol. 2019, 10, 3099. [CrossRef]

12. Takaba, H.; Takayanagi, H. The Mechanisms of T cell selection in the thymus. Trends Immunol. 2017, 38, 805-816. [CrossRef]

13. Ulyanchenko, S.; O’Neill, K.E.; Medley, T.; Farley, A.M.; Vaidya, H.J.; Cook, A.M.; Blair, N.F.; Blackburn, C.C. Identification of a Bipotent Epithelial Progenitor Population in the Adult Thymus. Cell Rep. 2016, 14, 2819-2832. [CrossRef] [PubMed]

14. Wong, K.; Lister, N.L.; Barsanti, M.; Lim, J.M.; Hammett, M.V.; Khong, D.M.; Siatskas, C.; Gray, D.H.; Boyd, R.L.; Chidgey, A.P. Multilineage potential and self-renewal define an epithelial progenitor cell population in the adult thymus. Cell Rep. 2014, 8, 1198-1209. [CrossRef] [PubMed]

15. Lepletier, A.; Hun, M.L.; Hammett, M.V.; Wong, K.; Naeem, H.; Hedger, M.; Loveland, K.; Chidgey, A.P. Interplay between Follistatin, Activin A, and BMP4 Signaling Regulates Postnatal Thymic Epithelial Progenitor Cell Differentiation during Aging. Cell Rep. 2019, 27, 3887-3901.e4. [CrossRef]

16. Gill, J.; Malin, M.; Hollander, G.A.; Boyd, R. Generation of a complete thymic microenvironment by MTS24(+) thymic epithelial cells. Nat. Immunol. 2002, 3, 635-642. [CrossRef] [PubMed]

17. Rossi, S.W.; Jenkinson, W.E.; Anderson, G.; Jenkinson, E.J. Clonal analysis reveals a common progenitor for thymic cortical and medullary epithelium. Nature 2006, 441, 988-991. [CrossRef] [PubMed]

18. Bennett, A.R.; Farley, A.; Blair, N.F.; Gordon, J.; Sharp, L.; Blackburn, C.C. Identification and characterization of thymic epithelial progenitor cells. Immunity 2002, 16, 803-814. [CrossRef] 
19. Mayer, C.E.; Zuklys, S.; Zhanybekova, S.; Ohigashi, I.; Teh, H.Y.; Sansom, S.N.; Shikama-Dorn, N.; Hafen, K.; Macaulay, I.C.; Deadman, M.E.; et al. Dynamic spatio-temporal contribution of single beta5t+ cortical epithelial precursors to the thymus medulla. Eur. J. Immunol. 2016, 46, 846-856. [CrossRef]

20. Ohigashi, I.; Zuklys, S.; Sakata, M.; Mayer, C.E.; Hamazaki, Y.; Minato, N.; Hollander, G.A.; Takahama, Y. Adult Thymic Medullary Epithelium Is Maintained and Regenerated by Lineage-Restricted Cells Rather Than Bipotent Progenitors. Cell Rep. 2015, 13, 1432-1443. [CrossRef]

21. Baik, S.; Jenkinson, E.J.; Lane, P.J.; Anderson, G.; Jenkinson, W.E. Generation of both cortical and Aire(+) medullary thymic epithelial compartments from CD205(+) progenitors. Eur. J. Immunol. 2013, 43, 589-594. [CrossRef]

22. Ohigashi, I.; Zuklys, S.; Sakata, M.; Mayer, C.E.; Zhanybekova, S.; Murata, S.; Tanaka, K.; Hollander, G.A.; Takahama, Y. Aire-expressing thymic medullary epithelial cells originate from beta5t-expressing progenitor cells. Proc. Natl. Acad. Sci. USA 2013, 110, 9885-9890. [CrossRef]

23. Ribeiro, A.R.; Rodrigues, P.M.; Meireles, C.; Di Santo, J.P.; Alves, N.L. Thymocyte selection regulates the homeostasis of IL-7-expressing thymic cortical epithelial cells in vivo. J. Immunol. 2013, 191, 1200-1209. [CrossRef] [PubMed]

24. Takahama, Y.; Ohigashi, I.; Baik, S.; Anderson, G. Generation of diversity in thymic epithelial cells. Nat. Rev. Immunol. 2017, 17, 295-305. [CrossRef] [PubMed]

25. Meireles, C.; Ribeiro, A.R.; Pinto, R.D.; Leitao, C.; Rodrigues, P.M.; Alves, N.L. Thymic crosstalk restrains the pool of cortical thymic epithelial cells with progenitor properties. Eur. J. Immunol. 2017, 47, 958-969. [CrossRef] [PubMed]

26. Bornstein, C.; Nevo, S.; Giladi, A.; Kadouri, N.; Pouzolles, M.; Gerbe, F.; David, E.; Machado, A.; Chuprin, A.; Toth, B.; et al. Single-cell mapping of the thymic stroma identifies IL-25-producing tuft epithelial cells. Nature 2018, 559, 622-626. [CrossRef]

27. Dumont-Lagace, M.; Gerbe, H.; Daouda, T.; Laverdure, J.P.; Brochu, S.; Lemieux, S.; Gagnon, E.; Perreault, C. Detection of Quiescent Radioresistant Epithelial Progenitors in the Adult Thymus. Front. Immunol. 2017, 8 , 1717. [CrossRef]

28. Shakib, S.; Desanti, G.E.; Jenkinson, W.E.; Parnell, S.M.; Jenkinson, E.J.; Anderson, G. Checkpoints in the development of thymic cortical epithelial cells. J. Immunol. 2009, 182, 130-137. [CrossRef]

29. Alves, N.L.; Richard-Le Goff, O.; Huntington, N.D.; Sousa, A.P.; Ribeiro, V.S.; Bordack, A.; Vives, F.L.; Peduto, L.; Chidgey, A.; Cumano, A.; et al. Characterization of the thymic IL-7 niche in vivo. Proc. Natl. Acad. Sci. USA 2009, 106, 1512-1517. [CrossRef]

30. Shitara, S.; Hara, T.; Liang, B.; Wagatsuma, K.; Zuklys, S.; Hollander, G.A.; Nakase, H.; Chiba, T.; Tani-ichi, S.; Ikuta, K. IL-7 produced by thymic epithelial cells plays a major role in the development of thymocytes and TCRgammadelta+ intraepithelial lymphocytes. J. Immunol. 2013, 190, 6173-6179. [CrossRef]

31. Koch, U.; Fiorini, E.; Benedito, R.; Besseyrias, V.; Schuster-Gossler, K.; Pierres, M.; Manley, N.R.; Duarte, A.; Macdonald, H.R.; Radtke, F. Delta-like 4 is the essential, nonredundant ligand for Notch1 during thymic T cell lineage commitment. J. Exp. Med. 2008, 205, 2515-2523. [CrossRef]

32. Hozumi, K.; Mailhos, C.; Negishi, N.; Hirano, K.; Yahata, T.; Ando, K.; Zuklys, S.; Hollander, G.A.; Shima, D.T.; $\mathrm{Habu}, \mathrm{S}$. Delta-like 4 is indispensable in thymic environment specific for T cell development. J. Exp. Med. 2008, 205, 2507-2513. [CrossRef]

33. Gray, D.H.; Seach, N.; Ueno, T.; Milton, M.K.; Liston, A.; Lew, A.M.; Goodnow, C.C.; Boyd, R.L. Developmental kinetics, turnover, and stimulatory capacity of thymic epithelial cells. Blood 2006, 108, 3777-3785. [CrossRef] [PubMed]

34. Yang, S.J.; Ahn, S.; Park, C.S.; Holmes, K.L.; Westrup, J.; Chang, C.H.; Kim, M.G. The quantitative assessment of MHC II on thymic epithelium: Implications in cortical thymocyte development. Int. Immunol. 2006, 18, 729-739. [CrossRef] [PubMed]

35. Cejalvo, T.; Munoz, J.J.; Tobajas, E.; Fanlo, L.; Alfaro, D.; Garcia-Ceca, J.; Zapata, A. Ephrin-B-dependent thymic epithelial cell-thymocyte interactions are necessary for correct $\mathrm{T}$ cell differentiation and thymus histology organization: Relevance for thymic cortex development. J. Immunol. 2013, 190, 2670-2681. [CrossRef] [PubMed]

36. Billiard, F.; Kirshner, J.R.; Tait, M.; Danave, A.; Taheri, S.; Zhang, W.; Waite, J.C.; Olson, K.; Chen, G.; Coetzee, S.; et al. Ongoing Dll4-Notch signaling is required for T-cell homeostasis in the adult thymus. Eur. J. Immunol. 2011, 41, 2207-2216. [CrossRef] 
37. Fiorini, E.; Ferrero, I.; Merck, E.; Favre, S.; Pierres, M.; Luther, S.A.; MacDonald, H.R. Cutting edge: Thymic crosstalk regulates delta-like 4 expression on cortical epithelial cells. J. Immunol. 2008, 181, 8199-8203. [CrossRef]

38. Tussiwand, R.; Engdahl, C.; Gehre, N.; Bosco, N.; Ceredig, R.; Rolink, A.G. The preTCR-dependent DN3 to DP transition requires Notch signaling, is improved by CXCL12 signaling and is inhibited by IL-7 signaling. Eur. J. Immunol. 2011, 41, 3371-3380. [CrossRef]

39. Carpenter, A.C.; Bosselut, R. Decision checkpoints in the thymus. Nat. Immunol. 2010, 11, 666-673. [CrossRef]

40. Kim, S.T.; Takeuchi, K.; Sun, Z.Y.; Touma, M.; Castro, C.E.; Fahmy, A.; Lang, M.J.; Wagner, G.; Reinherz, E.L. The alphabeta $\mathrm{T}$ cell receptor is an anisotropic mechanosensor. J. Biol. Chem. 2009, 284, 31028-31037. [CrossRef]

41. Yamasaki, S.; Ishikawa, E.; Sakuma, M.; Ogata, K.; Sakata-Sogawa, K.; Hiroshima, M.; Wiest, D.L.; Tokunaga, M.; Saito, T. Mechanistic basis of pre-T cell receptor-mediated autonomous signaling critical for thymocyte development. Nat. Immunol. 2006, 7, 67-75. [CrossRef]

42. Egawa, T.; Tillman, R.E.; Naoe, Y.; Taniuchi, I.; Littman, D.R. The role of the Runx transcription factors in thymocyte differentiation and in homeostasis of naive T cells. J. Exp. Med. 2007, 204, 1945-1957. [CrossRef]

43. Murata, S.; Sasaki, K.; Kishimoto, T.; Niwa, S.; Hayashi, H.; Takahama, Y.; Tanaka, K. Regulation of CD8+ T cell development by thymus-specific proteasomes. Science 2007, 316, 1349-1353. [CrossRef] [PubMed]

44. Nitta, T.; Murata, S.; Sasaki, K.; Fujii, H.; Ripen, A.M.; Ishimaru, N.; Koyasu, S.; Tanaka, K.; Takahama, Y. Thymoproteasome shapes immunocompetent repertoire of CD8+ T cells. Immunity 2010, 32, 29-40. [CrossRef] [PubMed]

45. Takada, K.; Van Laethem, F.; Xing, Y.; Akane, K.; Suzuki, H.; Murata, S.; Tanaka, K.; Jameson, S.C.; Singer, A.; Takahama, Y. TCR affinity for thymoproteasome-dependent positively selecting peptides conditions antigen responsiveness in CD8(+) T cells. Nat. Immunol. 2015, 16, 1069-1076. [CrossRef] [PubMed]

46. Nakagawa, T.; Roth, W.; Wong, P.; Nelson, A.; Farr, A.; Deussing, J.; Villadangos, J.A.; Ploegh, H.; Peters, C.; Rudensky, A.Y. Cathepsin L: Critical role in Ii degradation and CD4 T cell selection in the thymus. Science 1998, 280, 450-453. [CrossRef]

47. Gommeaux, J.; Gregoire, C.; Nguessan, P.; Richelme, M.; Malissen, M.; Guerder, S.; Malissen, B.; Carrier, A. Thymus-specific serine protease regulates positive selection of a subset of CD4+ thymocytes. Eur. J. Immunol. 2009, 39, 956-964. [CrossRef]

48. Dhalla, F.; Baran-Gale, J.; Maio, S.; Chappell, L.; Hollander, G.A.; Ponting, C.P. Biologically indeterminate yet ordered promiscuous gene expression in single medullary thymic epithelial cells. EMBO J. 2020, 39, e101828. [CrossRef]

49. Hamazaki, Y.; Fujita, H.; Kobayashi, T.; Choi, Y.; Scott, H.S.; Matsumoto, M.; Minato, N. Medullary thymic epithelial cells expressing Aire represent a unique lineage derived from cells expressing claudin. Nat. Immunol. 2007, 8, 304-311. [CrossRef]

50. Miller, C.N.; Proekt, I.; von Moltke, J.; Wells, K.L.; Rajpurkar, A.R.; Wang, H.; Rattay, K.; Khan, I.S.; Metzger, T.C.; Pollack, J.L.; et al. Thymic tuft cells promote an IL-4-enriched medulla and shape thymocyte development. Nature 2018, 559, 627-631. [CrossRef]

51. White, A.J.; Withers, D.R.; Parnell, S.M.; Scott, H.S.; Finke, D.; Lane, P.J.; Jenkinson, E.J.; Anderson, G. Sequential phases in the development of Aire-expressing medullary thymic epithelial cells involve distinct cellular input. Eur. J. Immunol. 2008, 38, 942-947. [CrossRef]

52. Gray, D.; Abramson, J.; Benoist, C.; Mathis, D. Proliferative arrest and rapid turnover of thymic epithelial cells expressing Aire. J. Exp. Med. 2007, 204, 2521-2528. [CrossRef]

53. Michel, C.; Miller, C.N.; Kuchler, R.; Brors, B.; Anderson, M.S.; Kyewski, B.; Pinto, S. Revisiting the Road Map of Medullary Thymic Epithelial Cell Differentiation. J. Immunol. 2017, 199, 3488-3503. [CrossRef] [PubMed]

54. Metzger, T.C.; Khan, I.S.; Gardner, J.M.; Mouchess, M.L.; Johannes, K.P.; Krawisz, A.K.; Skrzypczynska, K.M.; Anderson, M.S. Lineage tracing and cell ablation identify a post-Aire-expressing thymic epithelial cell population. Cell Rep. 2013, 5, 166-179. [CrossRef] [PubMed]

55. Nishikawa, Y.; Nishijima, H.; Matsumoto, M.; Morimoto, J.; Hirota, F.; Takahashi, S.; Luche, H.; Fehling, H.J.; Mouri, Y.; Matsumoto, M. Temporal lineage tracing of Aire-expressing cells reveals a requirement for Aire in their maturation program. J. Immunol. 2014, 192, 2585-2592. [CrossRef] [PubMed] 
56. Onder, L.; Nindl, V.; Scandella, E.; Chai, Q.; Cheng, H.W.; Caviezel-Firner, S.; Novkovic, M.; Bomze, D.; Maier, R.; Mair, F.; et al. Alternative NF-kappaB signaling regulates mTEC differentiation from podoplanin-expressing precursors in the cortico-medullary junction. Eur. J. Immunol. 2015, 45, 2218-2231. [CrossRef] [PubMed]

57. Wang, X.; Laan, M.; Bichele, R.; Kisand, K.; Scott, H.S.; Peterson, P. Post-Aire maturation of thymic medullary epithelial cells involves selective expression of keratinocyte-specific autoantigens. Front. Immunol. 2012, 3, 19. [CrossRef] [PubMed]

58. Miragaia, R.J.; Zhang, X.; Gomes, T.; Svensson, V.; Ilicic, T.; Henriksson, J.; Kar, G.; Lonnberg, T. Single-cell RNA-sequencing resolves self-antigen expression during mTEC development. Sci. Rep. 2018, 8, 685. [CrossRef]

59. Rossi, S.W.; Kim, M.Y.; Leibbrandt, A.; Parnell, S.M.; Jenkinson, W.E.; Glanville, S.H.; McConnell, F.M.; Scott, H.S.; Penninger, J.M.; Jenkinson, E.J.; et al. RANK signals from CD4(+)3(-) inducer cells regulate development of Aire-expressing epithelial cells in the thymic medulla. J. Exp. Med. 2007, 204, 1267-1272. [CrossRef]

60. Akiyama, T.; Shimo, Y.; Yanai, H.; Qin, J.; Ohshima, D.; Maruyama, Y.; Asaumi, Y.; Kitazawa, J.; Takayanagi, H.; Penninger, J.M.; et al. The tumor necrosis factor family receptors RANK and CD40 cooperatively establish the thymic medullary microenvironment and self-tolerance. Immunity 2008, 29, 423-437. [CrossRef]

61. Hikosaka, Y.; Nitta, T.; Ohigashi, I.; Yano, K.; Ishimaru, N.; Hayashi, Y.; Matsumoto, M.; Matsuo, K.; Penninger, J.M.; Takayanagi, H.; et al. The cytokine RANKL produced by positively selected thymocytes fosters medullary thymic epithelial cells that express autoimmune regulator. Immunity 2008, 29, 438-450. [CrossRef]

62. Irla, M.; Hugues, S.; Gill, J.; Nitta, T.; Hikosaka, Y.; Williams, I.R.; Hubert, F.X.; Scott, H.S.; Takahama, Y.; Hollander, G.A.; et al. Autoantigen-specific interactions with CD4+ thymocytes control mature medullary thymic epithelial cell cellularity. Immunity 2008, 29, 451-463. [CrossRef]

63. Finnish-German, A.C. An autoimmune disease, APECED, caused by mutations in a novel gene featuring two PHD-type zinc-finger domains. Nat. Genet. 1997, 17, 399-403.

64. Nagamine, K.; Peterson, P.; Scott, H.S.; Kudoh, J.; Minoshima, S.; Heino, M.; Krohn, K.J.; Lalioti, M.D.; Mullis, P.E.; Antonarakis, S.E.; et al. Positional cloning of the APECED gene. Nat. Genet. 1997, 17, 393-398. [CrossRef] [PubMed]

65. Perheentupa, J. Autoimmune polyendocrinopathy-candidiasis-ectodermal dystrophy. J. Clin. Endocrinol. Metab. 2006, 91, 2843-2850. [CrossRef]

66. Kisand, K.; Boe Wolff, A.S.; Podkrajsek, K.T.; Tserel, L.; Link, M.; Kisand, K.V.; Ersvaer, E.; Perheentupa, J.; Erichsen, M.M.; Bratanic, N.; et al. Chronic mucocutaneous candidiasis in APECED or thymoma patients correlates with autoimmunity to Th17-associated cytokines. J. Exp. Med. 2010, 207, 299-308. [CrossRef]

67. Puel, A.; Doffinger, R.; Natividad, A.; Chrabieh, M.; Barcenas-Morales, G.; Picard, C.; Cobat, A.; Ouachee-Chardin, M.; Toulon, A.; Bustamante, J.; et al. Autoantibodies against IL-17A, IL-17F, and IL-22 in patients with chronic mucocutaneous candidiasis and autoimmune polyendocrine syndrome type I. J. Exp. Med. 2010, 207, 291-297. [CrossRef] [PubMed]

68. Meloni, A.; Furcas, M.; Cetani, F.; Marcocci, C.; Falorni, A.; Perniola, R.; Pura, M.; Boe Wolff, A.S.; Husebye, E.S.; Lilic, D.; et al. Autoantibodies against type I interferons as an additional diagnostic criterion for autoimmune polyendocrine syndrome type I. J. Clin. Endocrinol. Metab. 2008, 93, 4389-4397. [CrossRef] [PubMed]

69. Liston, A.; Lesage, S.; Wilson, J.; Peltonen, L.; Goodnow, C.C. Aire regulates negative selection of organ-specific T cells. Nat. Immunol. 2003, 4, 350-354. [CrossRef] [PubMed]

70. Anderson, M.S.; Venanzi, E.S.; Chen, Z.; Berzins, S.P.; Benoist, C.; Mathis, D. The cellular mechanism of Aire control of T cell tolerance. Immunity 2005, 23, 227-239. [CrossRef]

71. Taniguchi, R.T.; DeVoss, J.J.; Moon, J.J.; Sidney, J.; Sette, A.; Jenkins, M.K.; Anderson, M.S. Detection of an autoreactive T-cell population within the polyclonal repertoire that undergoes distinct autoimmune regulator (Aire)-mediated selection. Proc. Natl. Acad. Sci. USA 2012, 109, 7847-7852. [CrossRef]

72. Malchow, S.; Leventhal, D.S.; Nishi, S.; Fischer, B.I.; Shen, L.; Paner, G.P.; Amit, A.S.; Kang, C.; Geddes, J.E.; Allison, J.P.; et al. Aire-dependent thymic development of tumor-associated regulatory T cells. Science 2013, 339, 1219-1224. [CrossRef] 
73. Perry, J.S.A.; Lio, C.J.; Kau, A.L.; Nutsch, K.; Yang, Z.; Gordon, J.I.; Murphy, K.M.; Hsieh, C.S. Distinct contributions of Aire and antigen-presenting-cell subsets to the generation of self-tolerance in the thymus. Immunity 2014, 41, 414-426. [CrossRef] [PubMed]

74. Yang, S.; Fujikado, N.; Kolodin, D.; Benoist, C.; Mathis, D. Immune tolerance. Regulatory T cells generated early in life play a distinct role in maintaining self-tolerance. Science 2015, 348, 589-594. [CrossRef] [PubMed]

75. Kyewski, B.; Derbinski, J. Self-representation in the thymus: An extended view. Nat. Rev. Immunol. 2004, 4, 688-698. [CrossRef] [PubMed]

76. Passos, G.A.; Speck-Hernandez, C.A.; Assis, A.F.; Mendes-da-Cruz, D.A. Update on Aire and thymic negative selection. Immunology 2018, 153, 10-20. [CrossRef] [PubMed]

77. Sansom, S.N.; Shikama-Dorn, N.; Zhanybekova, S.; Nusspaumer, G.; Macaulay, I.C.; Deadman, M.E.; Heger, A.; Ponting, C.P.; Hollander, G.A. Population and single-cell genomics reveal the Aire dependency, relief from Polycomb silencing, and distribution of self-antigen expression in thymic epithelia. Genome Res. 2014, 24, 1918-1931. [CrossRef] [PubMed]

78. Meredith, M.; Zemmour, D.; Mathis, D.; Benoist, C. Aire controls gene expression in the thymic epithelium with ordered stochasticity. Nat. Immunol. 2015, 16, 942-949. [CrossRef] [PubMed]

79. Brennecke, P.; Reyes, A.; Pinto, S.; Rattay, K.; Nguyen, M.; Kuchler, R.; Huber, W.; Kyewski, B.; Steinmetz, L.M. Single-cell transcriptome analysis reveals coordinated ectopic gene-expression patterns in medullary thymic epithelial cells. Nat. Immunol 2015, 16, 933-941. [CrossRef] [PubMed]

80. Anderson, M.S.; Venanzi, E.S.; Klein, L.; Chen, Z.; Berzins, S.P.; Turley, S.J.; von Boehmer, H.; Bronson, R.; Dierich, A.; Benoist, C.; et al. Projection of an immunological self shadow within the thymus by the aire protein. Science 2002, 298, 1395-1401. [CrossRef]

81. Takaba, H.; Morishita, Y.; Tomofuji, Y.; Danks, L.; Nitta, T.; Komatsu, N.; Kodama, T.; Takayanagi, H. Fezf2 Orchestrates a Thymic Program of Self-Antigen Expression for Immune Tolerance. Cell 2015, 163, 975-987. [CrossRef]

82. Cosway, E.J.; Lucas, B.; James, K.D.; Parnell, S.M.; Carvalho-Gaspar, M.; White, A.J.; Tumanov, A.V.; Jenkinson, W.E.; Anderson, G. Redefining thymus medulla specialization for central tolerance. J. Exp. Med. 2017, 214, 3183-3195. [CrossRef]

83. Bonasio, R.; Scimone, M.L.; Schaerli, P.; Grabie, N.; Lichtman, A.H.; von Andrian, U.H. Clonal deletion of thymocytes by circulating dendritic cells homing to the thymus. Nat. Immunol. 2006, 7, 1092-1100. [CrossRef] [PubMed]

84. Hadeiba, H.; Butcher, E.C. Thymus-homing dendritic cells in central tolerance. Eur. J. Immunol. 2013, 43, 1425-1459. [CrossRef]

85. Leventhal, D.S.; Gilmore, D.C.; Berger, J.M.; Nishi, S.; Lee, V.; Malchow, S.; Kline, D.E.; Kline, J.; Vander Griend, D.J.; Huang, H.; et al. Dendritic Cells Coordinate the Development and Homeostasis of Organ-Specific Regulatory T Cells. Immunity 2016, 44, 847-859. [CrossRef] [PubMed]

86. Mbongue, J.; Nicholas, D.; Firek, A.; Langridge, W. The role of dendritic cells in tissue-specific autoimmunity. J. Immunol. Res. 2014, 2014, 857143. [CrossRef] [PubMed]

87. Proietto, A.I.; van Dommelen, S.; Zhou, P.; Rizzitelli, A.; D'Amico, A.; Steptoe, R.J.; Naik, S.H.; Lahoud, M.H.; Liu, Y.; Zheng, P.; et al. Dendritic cells in the thymus contribute to T-regulatory cell induction. Proc. Natl. Acad. Sci. USA 2008, 105, 19869-19874. [CrossRef] [PubMed]

88. Hubert, F.X.; Kinkel, S.A.; Davey, G.M.; Phipson, B.; Mueller, S.N.; Liston, A.; Proietto, A.I.; Cannon, P.Z.; Forehan, S.; Smyth, G.K.; et al. Aire regulates the transfer of antigen from mTECs to dendritic cells for induction of thymic tolerance. Blood 2011, 118, 2462-2472. [CrossRef] [PubMed]

89. Mouri, Y.; Ueda, Y.; Yamano, T.; Matsumoto, M.; Tsuneyama, K.; Kinashi, T.; Matsumoto, M. Mode of Tolerance Induction and Requirement for Aire Are Governed by the Cell Types That Express Self-Antigen and Those That Present Antigen. J. Immunol. 2017, 199, 3959-3971. [CrossRef]

90. Yano, M.; Kuroda, N.; Han, H.; Meguro-Horike, M.; Nishikawa, Y.; Kiyonari, H.; Maemura, K.; Yanagawa, Y.; Obata, K.; Takahashi, S.; et al. Aire controls the differentiation program of thymic epithelial cells in the medulla for the establishment of self-tolerance. J. Exp. Med. 2008, 205, 2827-2838. [CrossRef]

91. Nishikawa, Y.; Hirota, F.; Yano, M.; Kitajima, H.; Miyazaki, J.; Kawamoto, H.; Mouri, Y.; Matsumoto, M. Biphasic Aire expression in early embryos and in medullary thymic epithelial cells before end-stage terminal differentiation. J. Exp. Med. 2010, 207, 963-971. [CrossRef] 
92. Odaka, C.; Hauri-Hohl, M.; Takizawa, K.; Nishikawa, Y.; Yano, M.; Matsumoto, M.; Boyd, R.; Hollander, G.A. TGF-beta type II receptor expression in thymic epithelial cells inhibits the development of Hassall's corpuscles in mice. Int. Immunol. 2013, 25, 633-642. [CrossRef]

93. Watanabe, N.; Wang, Y.H.; Lee, H.K.; Ito, T.; Wang, Y.H.; Cao, W.; Liu, Y.J. Hassall's corpuscles instruct dendritic cells to induce CD4+CD25+ regulatory T cells in human thymus. Nature 2005, 436, 1181-1185. [CrossRef]

94. Banerjee, A.; McKinley, E.T.; von Moltke, J.; Coffey, R.J.; Lau, K.S. Interpreting heterogeneity in intestinal tuft cell structure and function. J. Clin. Investig. 2018, 128, 1711-1719. [CrossRef] [PubMed]

95. Gerbe, F.; Legraverend, C.; Jay, P. The intestinal epithelium tuft cells: Specification and function. Cell. Mol. Life Sci. 2012, 69, 2907-2917. [CrossRef] [PubMed]

96. Panneck, A.R.; Rafiq, A.; Schutz, B.; Soultanova, A.; Deckmann, K.; Chubanov, V.; Gudermann, T.; Weihe, E.; Krasteva-Christ, G.; Grau, V.; et al. Cholinergic epithelial cell with chemosensory traits in murine thymic medulla. Cell Tissue Res. 2014, 358, 737-748. [CrossRef] [PubMed]

97. Soultanova, A.; Voigt, A.; Chubanov, V.; Gudermann, T.; Meyerhof, W.; Boehm, U.; Kummer, W. Cholinergic chemosensory cells of the thymic medulla express the bitter receptor Tas2r131. Int. Immunopharmacol. 2015, 29, 143-147. [CrossRef] [PubMed]

98. Munoz, J.J.; Garcia-Ceca, J.; Montero-Herradon, S.; Sanchez Del Collado, B.; Alfaro, D.; Zapata, A. Can a Proper T-Cell Development Occur in an Altered Thymic Epithelium? Lessons from EphB-Deficient Thymi. Front. Endocrinol. 2018, 9, 135. [CrossRef]

99. Osada, M.; Ito, E.; Fermin, H.A.; Vazquez-Cintron, E.; Venkatesh, T.; Friedel, R.H.; Pezzano, M. The Wnt signaling antagonist Kremen1 is required for development of thymic architecture. Clin. Dev. Immunol. 2006, 13, 299-319. [CrossRef]

100. Revest, J.M.; Suniara, R.K.; Kerr, K.; Owen, J.J.; Dickson, C. Development of the thymus requires signaling through the fibroblast growth factor receptor R2-IIIb. J. Immunol. 2001, 167, 1954-1961. [CrossRef]

101. Lomada, D.; Jain, M.; Bolner, M.; Reeh, K.A.; Kang, R.; Reddy, M.C.; DiGiovanni, J.; Richie, E.R. Stat3 Signaling Promotes Survival and Maintenance of Medullary Thymic Epithelial Cells. PLoS Genet. 2016, 12, e1005777. [CrossRef]

102. Munoz, J.J.; Alonso, C.L.; Sacedon, R.; Crompton, T.; Vicente, A.; Jimenez, E.; Varas, A.; Zapata, A.G. Expression and function of the Eph A receptors and their ligands ephrins A in the rat thymus. J. Immunol. 2002, 169, 177-184. [CrossRef]

103. Garcia-Ceca, J.; Alfaro, D.; Montero-Herradon, S.; Tobajas, E.; Munoz, J.J.; Zapata, A.G. Eph/Ephrins-Mediated Thymocyte-Thymic Epithelial Cell Interactions Control Numerous Processes of Thymus Biology. Front. Immunol. 2015, 6, 333. [CrossRef] [PubMed]

104. Himanen, J.P.; Saha, N.; Nikolov, D.B. Cell-cell signaling via Eph receptors and ephrins. Curr. Opin. Cell. Biol. 2007, 19, 534-542. [CrossRef]

105. Pasquale, E.B. Eph receptor signalling casts a wide net on cell behaviour. Nat. Rev. Mol. Cell Biol. 2005, 6, 462-475. [CrossRef] [PubMed]

106. Knoll, B.; Drescher, U. Ephrin-As as receptors in topographic projections. Trends Neurosci. 2002, 25, 145-149. [CrossRef]

107. Alfaro, D.; Munoz, J.J.; Garcia-Ceca, J.; Cejalvo, T.; Jimenez, E.; Zapata, A. Alterations in the thymocyte phenotype of EphB-deficient mice largely affect the double negative cell compartment. Immunology 2008, 125, 131-143. [CrossRef] [PubMed]

108. Montero-Herradon, S.; Garcia-Ceca, J.; Sanchez Del Collado, B.; Alfaro, D.; Zapata, A.G. Eph/ephrin-B-mediated cell-to-cell interactions govern MTS20(+) thymic epithelial cell development. Histochem. Cell Biol. 2016, 146, 167-182. [CrossRef]

109. Garcia-Ceca, J.; Jimenez, E.; Alfaro, D.; Cejalvo, T.; Chumley, M.J.; Henkemeyer, M.; Munoz, J.J.; Zapata, A.G. On the role of Eph signalling in thymus histogenesis; EphB2/B3 and the organizing of the thymic epithelial network. Int. J. Dev. Biol. 2009, 53, 971-982. [CrossRef]

110. Montero-Herradon, S.; Garcia-Ceca, J.; Zapata, A.G. EphB receptors, mainly EphB3, contribute to the proper development of cortical thymic epithelial cells. Organogenesis 2017, 13, 192-211. [CrossRef]

111. Stimamiglio, M.A.; Jimenez, E.; Silva-Barbosa, S.D.; Alfaro, D.; Garcia-Ceca, J.J.; Munoz, J.J.; Cejalvo, T.; Savino, W.; Zapata, A. EphB2-mediated interactions are essential for proper migration of T cell progenitors during fetal thymus colonization. J. Leukoc. Biol. 2010, 88, 483-494. [CrossRef] 
112. Alfaro, D.; Garcia-Ceca, J.; Farias-de-Oliveira, D.A.; Terra-Granado, E.; Montero-Herradon, S.; Cotta-de-Almeida, V.; Savino, W.; Zapata, A. EphB2 and EphB3 play an important role in the lymphoid seeding of murine adult thymus. J. Leukoc. Biol. 2015, 98, 883-896. [CrossRef]

113. Luo, H.; Wu, Z.; Qi, S.; Jin, W.; Han, B.; Wu, J. Ephrinb1 and Ephrinb2 are associated with interleukin-7 receptor alpha and retard its internalization from the cell surface. J. Biol. Chem. 2011, 286, 44976-44987. [CrossRef] [PubMed]

114. Jenkinson, W.E.; Jenkinson, E.J.; Anderson, G. Differential requirement for mesenchyme in the proliferation and maturation of thymic epithelial progenitors. J. Exp. Med. 2003, 198, 325-332. [CrossRef] [PubMed]

115. Garcia-Ceca, J.; Alfaro, D.; Montero-Herradon, S.; Zapata, A.G. Eph/ephrinB signalling is involved in the survival of thymic epithelial cells. Immunol. Cell Biol. 2013, 91, 130-138. [CrossRef] [PubMed]

116. Rodewald, H.R.; Paul, S.; Haller, C.; Bluethmann, H.; Blum, C. Thymus medulla consisting of epithelial islets each derived from a single progenitor. Nature 2001, 414, 763-768. [CrossRef]

117. Montero-Herradon, S.; Garcia-Ceca, J.; Zapata, A.G. Altered Maturation of Medullary TEC in EphB-Deficient Thymi Is Recovered by RANK Signaling Stimulation. Front. Immunol. 2018, 9, 1020. [CrossRef]

118. Garcia-Ceca, J.; Montero-Herradon, S.; Alfaro, D.; Zapata, A.G. Increased epithelial-free areas in thymuses with altered EphB-mediated thymocyte-thymic epithelial cell interactions. Histochem. Cell Biol. 2017, 148, 381-394. [CrossRef]

119. Lucas, B.; McCarthy, N.I.; Baik, S.; Cosway, E.; James, K.D.; Parnell, S.M.; White, A.J.; Jenkinson, W.E.; Anderson, G. Control of the thymic medulla and its influence on alphabetaT-cell development. Immunol. Rev. 2016, 271, 23-37. [CrossRef]

120. Mouri, Y.; Yano, M.; Shinzawa, M.; Shimo, Y.; Hirota, F.; Nishikawa, Y.; Nii, T.; Kiyonari, H.; Abe, T.; Uehara, H.; et al. Lymphotoxin signal promotes thymic organogenesis by eliciting RANK expression in the embryonic thymic stroma. J. Immunol. 2011, 186, 5047-5057. [CrossRef]

121. McCarthy, N.I.; Cowan, J.E.; Nakamura, K.; Bacon, A.; Baik, S.; White, A.J.; Parnell, S.M.; Jenkinson, E.J.; Jenkinson, W.E.; Anderson, G. Osteoprotegerin-Mediated Homeostasis of Rank+ Thymic Epithelial Cells Does Not Limit Foxp3+ Regulatory T Cell Development. J. Immunol. 2015, 195, 2675-2682. [CrossRef]

122. Jin, W.; Luo, H.; Wu, J. Effect of reduced EPHB4 expression in thymic epithelial cells on thymocyte development and peripheral T cell function. Mol. Immunol. 2014, 58, 1-9. [CrossRef]

123. Shimoyama, M.; Matsuoka, H.; Nagata, A.; Iwata, N.; Tamekane, A.; Okamura, A.; Gomyo, H.; Ito, M.; Jishage, K.; Kamada, N.; et al. Developmental expression of EphB6 in the thymus: Lessons from EphB6 knockout mice. Biochem. Biophys. Res. Commun. 2002, 298, 87-94. [CrossRef]

124. Kawano, H.; Katayama, Y.; Minagawa, K.; Shimoyama, M.; Henkemeyer, M.; Matsui, T. A novel feedback mechanism by Ephrin-B1/B2 in T-cell activation involves a concentration-dependent switch from costimulation to inhibition. Eur. J. Immunol. 2012, 42, 1562-1572. [CrossRef] [PubMed]

125. Jin, W.; Qi, S.; Luo, H. The effect of conditional EFNB1 deletion in the T cell compartment on $\mathrm{T}$ cell development and function. BMC Immunol. 2011, 12, 68. [CrossRef] [PubMed]

126. Jin, W.; Qi, S.; Luo, H. T cell-specific deletion of EFNB2 minimally affects T cell development and function. Mol. Immunol. 2012, 52, 141-147. [CrossRef]

127. Luo, H.; Broux, B.; Wang, X.; Hu, Y.; Ghannam, S.; Jin, W.; Larochelle, C.; Prat, A.; Wu, J. EphrinB1 and EphrinB2 regulate $\mathrm{T}$ cell chemotaxis and migration in experimental autoimmune encephalomyelitis and multiple sclerosis. Neurobiol. Dis. 2016, 91, 292-306. [CrossRef]

128. Hu, Y.; Wang, X.; Wu, Y.; Jin, W.; Cheng, B.; Fang, X.; Martel-Pelletier, J.; Kapoor, M.; Peng, J.; Qi, S.; et al. Role of EFNB1 and EFNB2 in Mouse Collagen-Induced Arthritis and Human Rheumatoid Arthritis. Arthritis Rheumatol. 2015, 67, 1778-1788. [CrossRef]

129. Munoz, J.J.; Alfaro, D.; Garcia-Ceca, J.; Alonso, C.L.; Jimenez, E.; Zapata, A. Thymic alterations in EphA4-deficient mice. J. Immunol. 2006, 177, 804-813. [CrossRef]

130. Bruserud, O.; Oftedal, B.E.; Wolff, A.B.; Husebye, E.S. AIRE-mutations and autoimmune disease. Curr. Opin. Immunol. 2016, 43, 8-15. [CrossRef]

131. Gimenez-Barcons, M.; Casteras, A.; Armengol Mdel, P.; Porta, E.; Correa, P.A.; Marin, A.; Pujol-Borrell, R.; Colobran, R. Autoimmune predisposition in Down syndrome may result from a partial central tolerance failure due to insufficient intrathymic expression of AIRE and peripheral antigens. J. Immunol. 2014, 193, 3872-3879. [CrossRef] 
132. Nakagawa, Y.; Ohigashi, I.; Nitta, T.; Sakata, M.; Tanaka, K.; Murata, S.; Kanagawa, O.; Takahama, Y. Thymic nurse cells provide microenvironment for secondary $\mathrm{T}$ cell receptor alpha rearrangement in cortical thymocytes. Proc. Natl. Acad. Sci. USA 2012, 109, 20572-20577. [CrossRef]

133. Alfaro, D.; Munoz, J.J.; Garcia-Ceca, J.; Cejalvo, T.; Jimenez, E.; Zapata, A.G. The Eph/ephrinB signal balance determines the pattern of T-cell maturation in the thymus. Immunol. Cell Biol. 2011, 89, 844-852. [CrossRef] [PubMed]

134. Liston, A.; Gray, D.H.; Lesage, S.; Fletcher, A.L.; Wilson, J.; Webster, K.E.; Scott, H.S.; Boyd, R.L.; Peltonen, L.; Goodnow, C.C. Gene dosage-limiting role of Aire in thymic expression, clonal deletion, and organ-specific autoimmunity. J. Exp. Med. 2004, 200, 1015-1026. [CrossRef] [PubMed]

135. Su, M.A.; Giang, K.; Zumer, K.; Jiang, H.; Oven, I.; Rinn, J.L.; Devoss, J.J.; Johannes, K.P.; Lu, W.; Gardner, J.; et al. Mechanisms of an autoimmunity syndrome in mice caused by a dominant mutation in Aire. J. Clin. Investig. 2008, 118, 1712-1726. [CrossRef] [PubMed]

136. Klein, L.; Kyewski, B. Self-antigen presentation by thymic stromal cells: A subtle division of labor. Curr. Opin. Immunol. 2000, 12, 179-186. [CrossRef]

137. Lopes, N.; Serge, A.; Ferrier, P.; Irla, M. Thymic Crosstalk Coordinates Medulla Organization and T-Cell Tolerance Induction. Front. Immunol. 2015, 6, 365. [CrossRef]

138. Hasegawa, H.; Matsumoto, T. Mechanisms of Tolerance Induction by Dendritic Cells In Vivo. Front. Immunol. 2018, 9, 350. [CrossRef]

139. Garcia-Ceca, J.; Montero-Herradon, S.; Zapata, A.G. Thymus aging in mice deficient in either EphB2 or EphB3, two master regulators of thymic epithelium development. Dev. Dyn. 2020. [CrossRef]

140. Prockop, S.E.; Petrie, H.T. Regulation of thymus size by competition for stromal niches among early $\mathrm{T}$ cell progenitors. J. Immunol. 2004, 173, 1604-1611. [CrossRef]

141. Jenkinson, W.E.; Rossi, S.W.; Parnell, S.M.; Jenkinson, E.J.; Anderson, G. PDGFRalpha-expressing mesenchyme regulates thymus growth and the availability of intrathymic niches. Blood 2007, 109, 954-960. [CrossRef]

(C) 2020 by the authors. Licensee MDPI, Basel, Switzerland. This article is an open access article distributed under the terms and conditions of the Creative Commons Attribution (CC BY) license (http://creativecommons.org/licenses/by/4.0/). 